\title{
The Paradoxes of Secured Lending: IS THERe a LeSs Uneasy CaSe FOR THE PRIORITY OF SECURED CLAIMS IN BANKRUPTCY?
}

\author{
Wei Zhang*
}

INTRODUCTION .790

I. NONADJUSTING CREDITORS AND THE DiSTRIBUTIONAL EFFECTS

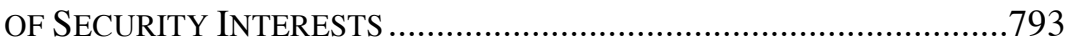

A. Distributional Effects of Secured Debt ....................................793

B. Presence of Nonadjusting Creditors .......................................794

C. Inefficiencies Resulting from the Distributional Effect............796

1. Costs of Granting Security Interests as a Net Welfare

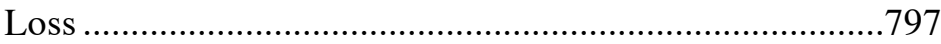

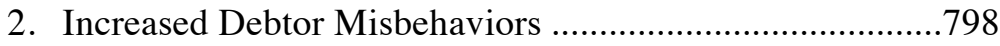

3. Lowered Precaution Against Tort Liabilities......................801

II. A REVIEW OF THE THEORIES ON THE EFFICIENCY OF SECURED

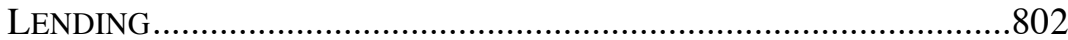

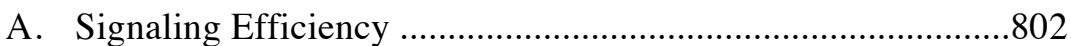

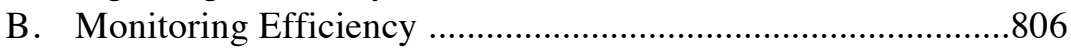

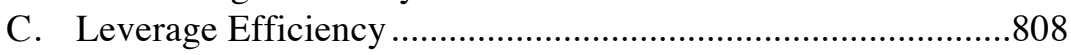

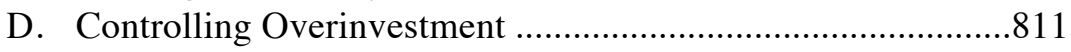

1. Disabling Asset Substitution .....................................................

2. Precluding Subsequent Borrowing to Finance Risky

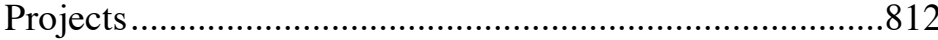

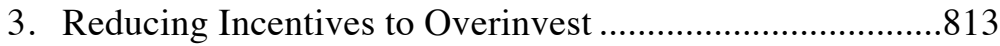

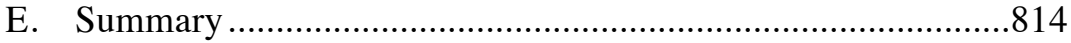

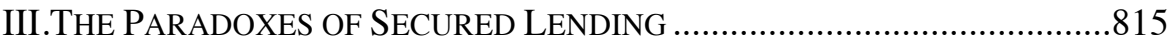

A. The Primary Paradox: Efficiency Residing in Distribution.....816

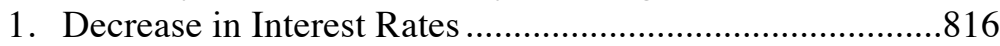

2. Presence of Nonadjusting Creditors...................................820

B. Secondary Paradox: Exacerbating and Alleviating

Overinvestment.

* Assistant Professor, Singapore Management University, School of Law (Ph.D. UC Berkeley School of Law, LL.M. Harvard Law School, M.A. Waseda University, B.A. Fudan University). 


\section{IV.MAJOR COSTS OF THE PARADOXICAL SECURED LENDING}

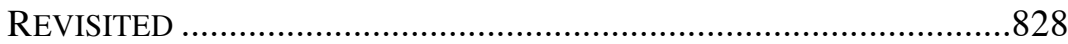

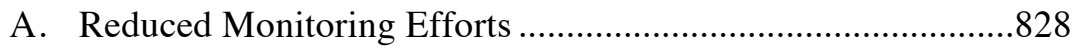

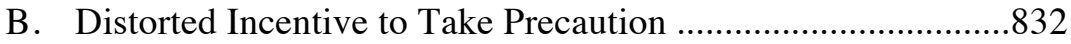

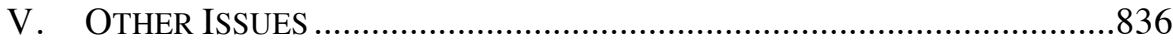

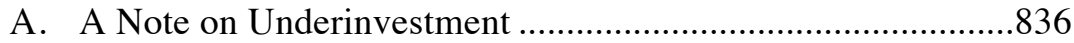

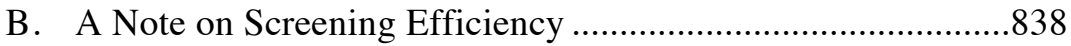

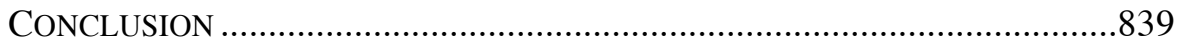

\section{INTRODUCTION}

Probably few legal devices are as confusing to an efficiency-oriented lawyer, yet have comparably widespread $^{1}$ and frequent $^{2}$ uses in our commercial life, as security interests. In the early 1980s, Professor Allen Schwartz introduced the "puzzle of secured debt," where secured lending was portrayed as a zero-sum game, maybe even with some net costs. ${ }^{3}$ Since then, plenty of attempts have been made in the legal academia to justify the efficiency of secured debts, though seemingly with only limited success. ${ }^{4}$ At the same time, the potential to redistribute wealth from certain

1. Virtually every country in the world recognizes at least some security devices, and according to the London attorney Phillip R. Wood, about eighty English-based states allow a universal monopolistic security over all assets of the debtor. LYNN M. LOPUCKI \& Elizabeth Warren, Secured Credit: A Systems Approach 410 (4th ed. 2003) (citing PHILIP R. WOOD, MAPS OF WORLd FinANCIAL LAW 24-25 (1997)).

2. Professor Listokin's recent study shows that in the U.S., for firms not subject to high risk of tort liabilities, about one-third of their debts are secured, though the ratio appears lower in the so-called "high-tort" firms. Yair Listokin, Is Secured Debt Used to Redistribute Value from Tort Claimants in Bankruptcy? An Empirical Analysis, 57 DukE L.J. 1037, 1062-63 (2008).

3. Alan Schwartz, The Continuing Puzzle of Secured Debt, 37 Vand. L. Rev. 1051 (1984) [hereinafter Schwartz, Continuing Puzzle]; see also Allen Schwartz, Security Interests and Bankruptcy Priorities: A Review of Current Theories, 10 J. LEGAL StUd. 1, 3 (1981) [hereinafter Schwartz, Security Interests]. For the details of the puzzle, see infra note 14 and accompanying text.

4. Important research by legal scholars on this subject has been conducted by, among others: Barry E. Adler, An Equity-Agency Solution to the Bankruptcy-Priority Puzzle, 22 J. LEgAl Stud. 73 (1993) [hereinafter Adler, Equity-Agency Solution]; F.H. Buckley, The Bankruptcy Priority Puzzle, 72 VA. L. REv. 1393 (1986); David Gray Carlson, On the Efficiency of Secured Lending, 80 VA. L. REV. 2179 (1994); Steven L. Harris \& Charles W. Mooney, Jr., A Property-Based Theory of Security Interests: Taking Debtors' Choices Seriously, 80 VA. L. REV. 2021 (1994); Thomas H. Jackson \& Anthony T. Kronman, Secured Financing and Priorities Among Creditors, 88 YALE L.J. 1143 (1979); Hideki Kanda \& Saul Levmore, Explaining Creditor Priorities, 80 VA. L. REV. 2103 (1994); Saul Levmore, Monitors and Freeriders in Commercial and Corporate Settings, 92 YALE L.J. 49 (1982); Ronald J. Mann, Explaining the Pattern of Secured Credit, 110 HARV. L. REv. 625 
groups of unsecured creditors has evoked severe doubts about the desirability of the priority statuses conferred upon secured creditors in bankruptcy. The most influential works expressing this concern are two articles co-authored by Professors Bebchuk and Fried at the eve of an overhaul of Article 9 of the Uniform Commercial Code. ${ }^{5}$

This Article is inspired directly by the Bebchuk and Fried articles, which comprehensively questioned the efficiency of the bankruptcy priority awarded to secured claims. The Article starts by pointing out an efficiency benefit of such priority largely unmentioned in the legal literature, including the Bebchuk and Fried articles. Namely, the priority of secured debts undermines borrowers' incentives to pursue excessively risky investment projects under certain circumstances. However, this additional benefit also exposes two interrelated paradoxes pertaining to the welfare effects of secured claims with bankruptcy priority. For one thing, the advantage of discouraging excessive risk-taking behaviors, and probably some other efficiency advantages too, rests exactly on the distribution effects of the priority enjoyed by secured lenders.

For another, while the issuance of secured senior debts helps constrain overly-risky investment incentives in some contexts, it nevertheless promotes these kinds of incentives in others. By identifying and elaborating on these paradoxes of secured lending, ${ }^{6}$ this Article contributes to the literature in two aspects. First, it underlines the overshadowed function of secured lending in attenuating overinvestment incentives, which so far has been left out of the calculus when most legal scholars assess the efficiency of secured debts. In particular, this study reminds us of the potential price of aggravated risk-taking behaviors if tort claims are entrenched with a superpriority status in bankruptcy, ${ }^{7}$ an issue barely

(1997); Randal C. Picker, Security Interests, Misbehavior, and Common Pools, 59 U. CHI. L. Rev. 645 (1992); Steven L. Schwarcz, The Easy Case for the Priority of Secured Claims in Bankruptcy, 47 DuKE L.J. 425 (1997); Robert E. Scott, A Relational Theory of Secured Financing, 86 Colum. L. REV. 901 (1986) [hereinafter Scott, Relational Theory]; George G. Triantis, Secured Debt Under Conditions of Imperfect Information, 21 J. LEGAL STUD. 225 (1992) [hereinafter Triantis, Secured Debt]; James J. White, Efficiency Justifications for Personal Property Security, 37 VAND. L. ReV. 473 (1984).

5. Lucian Arye Bebchuk \& Jesse M. Fried, The Uneasy Case for the Priority of Secured Claims in Bankruptcy, 105 YALE L.J. 857 (1996) [hereinafter Bebchuk \& Fried, Uneasy Case 1]; Lucian Arye Bebchuk \& Jesse M. Fried, The Uneasy Case for the Priority of Secured Claims in Bankruptcy: Further Thoughts and a Reply to Critics, 82 CORNELL L. REV. 1279 (1997) [hereinafter Bebchuk \& Fried, Uneasy Case 2].

6. To be more precise, these are the paradoxes arising from the priority of secured lending.

7. For suggestions on granting tort creditors superpriority in bankruptcy, see, for example, Buckley, supra note 4, at 1406, 1417; David W. Leebron, Limited Liability, Tort Victims, and Creditors, 91 Colum. L. Rev. 1565, 1646-49 (1991); Lynn M. LoPucki, The 
brought up in the literature.

Second, this Article also cautions the proponents of the secured credit priority system on the fragility of its presumed efficiency, which hinges substantially upon its distributional outcomes. The paradoxes discussed below will challenge the efforts to buttress the priority of secured claims by qualifying the scope of potential victims of its distributional effects. My discussion will show that the smaller the scope of the victims, the lower the significance of secured lending in boosting efficiency. Essentially, this Article extends the logic underlying the "puzzle of secured debt" to the efficiency analysis of secured lending from a broader perspective. Although it is not aimed specifically at offering new solutions to the puzzle, this paper does seek to clarify misunderstandings in previous works following primarily the framework laid down by Professor Schwartz. ${ }^{8}$

Theoretical studies on secured lending have gathered little attention since the late 1990s. Yet this vein of studies may take on new importance in light of the recent surge of second lien loans in the capital market.' Article 9 has evidently exerted extensive influence abroad as well. Many transitional economies in Eastern Europe actively took in the American style of non-possessory security interests in movable assets as they reformed their collateral regimes. ${ }^{10}$ China, in its new Property Law promulgated in 2007 , officially acknowledged the security interests in current and after-acquired equipment and inventories. ${ }^{11}$ In 2004, Japan amended its law on the filing of personal property and accounts receivable, ${ }^{12}$ apparently to facilitate the creation of these assets' security interests à la UCC. ${ }^{13}$ All these movements seem to be pressing for

Unsecured Creditor's Bargain, 80 VA. L. REV. 1887, 1913-14 (1994); Christopher M.E. Painter, Tort Creditor Priority in the Secured Creditor System: Asbestos Times, the Worst of Times, 36 STAN. L. ReV. 1045, 1080-83 (1984).

8. For the details of this framework, see infra note 14 and accompanying text.

9. See Douglas G. Baird \& Robert K. Rasmussen, Antibankruptcy, 119 YAlE L.J. 648, 671-75 (2010) (describing the robust market for second lien loans that has emerged in the past several years, in large part due to syndication of such loans and demand on the part of hedge funds).

10. Rainer Haselmann, Katharina Pistor \& Vikrant Vig, How Law Affects Lending, 23 REV. Fin. STUD. 549, 553-60 (2010).

11. Zhonghua Renmin Gongheguo Wu Quan Fa [Property Law of the People's Republic of China] (promulgated by Tenth Nat'l People's Cong., Mar. 16, 2007, effective Oct. 1, 2007), art. 181.

12. Dohsan Oyobi Saiken No Johto No Taikoh Yohken Ni Kansuru Minpoh No Tokureh Toh Ni Kansuru Hohritsu [Act on Special Provisions, etc. of the Civil Code Concerning the Perfection Requirements for the Assignment of Movables and Claims], Law No. 104 of 1998 (Japan).

13. Chieko Nohno, Saiken Johto No Taikoh Yohken Ni Kansuru Minpoh No Tokureh Toh Ni Kansuru Hohritsu No Yichibu Wo Kaisei Suru Hohritsu: Tehan Riyu [Reason for the Proposal of Amending the Act on Special Provisions, etc. of the Civil Code Concerning the 
continuing inquiries into the welfare outcomes of secured debts.

Below, Part I of this paper outlines the challenges to the efficiency of secured lending, especially when some creditors do not make adjustments in interest rates. Part II reviews theories on the efficiency of secured lending and analyzes whether any of them lends support to a less uneasy case for the priority of secured claims in bankruptcy. Part III fleshes out the two paradoxes of secured lending in terms of secured lending's effects on borrowers' overinvesting incentives. Part IV considers some additional costs that need to be balanced against the efficiency benefits of secured lending. Part V extends the paradoxical nature of secured lending to two other aspects of its efficiency effects: remedying underinvestment and saving in screening costs.

\section{NONADJUSTING CREDITORS AND THE DISTRIBUTIONAL EFFECTS OF SECURITY INTERESTS}

\section{A. Distributional Effects of Secured Debt}

By obtaining a priority over unsecured creditors when the debtor becomes insolvent and unable to pay off all its debts, secured creditors can extract more from the bankruptcy estate than a pro rata rule would otherwise have allowed. Thus, secured creditors are less vulnerable to the risk of the debtor's failure, and will charge lower interest rates accordingly. However, more assets going to secured creditors means that fewer are left for unsecured creditors in the event of the debtor's bankruptcy. In other words, to the extent that secured creditors are more risk-resistant, unsecured creditors become more risk-vulnerable. Therefore, if unsecured creditors can properly calculate the additional risk due to the existence of outstanding security interests, they will demand higher interests to compensate for it. As a whole, any decrease in interest rates applicable to secured debts will likely be cancelled out by the corresponding increase in interest charges applicable to unsecured debts; hence, the total amount of interest the debtor has to pay stays constant. Since issuing secured debts is costly, the now well-known "puzzle of secured debt" stands in the way of

Perfection Requirements for the Assignment of Claims] (at the Committee of Judicial Affairs, House of Councillors, the National Diet of Japan, Nov. 2, 2004):

[I]t has drawn great attention in recent years to create security interests in or securitize movables and claims for financing purposes .... Therefore, this amendment enables the public notice of the assignment of the movables and account receivables held by legal persons through filing, so as to facilitate the financing by enterprises using movables and claims. 
any serious effort to advocate for the efficiency of secured lending. ${ }^{14}$

However, the puzzle exists because of informed and adjusting unsecured creditors. If these creditors do not adjust interest rates to reflect the incremented risk, debtors can well enjoy the benefit of secured lending's reduced interest rates at the expense of unsecured creditors. Then, essentially, secured debt redistributes wealth from nonadjusting general creditors to the debtor. ${ }^{15}$ This kind of distributional effect has long been noted and has been used to explain the prevalence of secured lending in spite of certain potential empirical difficulties. ${ }^{16}$

\section{B. Presence of Nonadjusting Creditors}

Uninformed and nonadjusting creditors seem to exist. Hence, the distributional effect of secured lending is not a mere hypothetical. If the issuance of secured debts is mostly motivated by such a distributional effect, then the priority awarded to secured claims should be reconsidered since the negative externality suffered by nonadjusting creditors may encourage the debtor to undertake value-wasting investment projects. In fact, this is the main argument against the priority of secured claims in bankruptcy raised by Professors Bebchuk and Fried. ${ }^{17}$ In particular, they

14. Professor Schwartz listed four assumptions leading to this puzzle: Creditors $(i)$ can learn of and react to the existence of security; (ii) can calculate risks of default reasonably precisely; (iii) are risk-neutral; and (iv) have homogeneous expectations respecting default probabilities. Schwartz, Security Interests, supra note 3, at 7. Because it is focused on the situation with nonadjusting creditors, this Article will not discuss the assumptions about risk-neutrality and homogeneous expectations. For critiques on the efforts to resolve the puzzle by relaxing these two assumptions see id. at 22-24, 27-28; Schwartz, Continuing Puzzle, supra note 3, at 1062-66; Triantis, Secured Debt, supra note 4, at 227-28.

15. The term "nonadjusting creditor" was first introduced in Bebchuk and Fried's 1996 article, Bebchuk \& Fried, Uneasy Case 1, supra note 5, at 864. In a follow-up article published the following year, Bebchuk and Fried defined "nonadjusting creditors" as "creditors that do not adjust the terms of their loan to reflect the effect on them of the creation of security interests which, under full priority, completely subordinate the nonadjusting creditors' claims in bankruptcy." Bebchuk \& Fried, Uneasy Case 2, supra note 5 , at $1293-94$.

16. See Schwartz, Security Interests, supra note 3, at 30-33 (suggesting that such a distributional explanation incorrectly predicts the absence of security in cases when most of the creditors are aware of the security); James H. Scott Jr., Bankruptcy, Secured Debt, and Optimal Capital Structure, 32 J. FIN. 1 (1977) [hereinafter Scott, Bankruptcy] (asserting that secured debt can be used to increase stockholder wealth); James H. Scott Jr., Bankruptcy, Secured Debt, and Optimal Capital Structure: Reply, 34 J. FIN. 253 (1979) [hereinafter Scott, Reply] (verifying the claim that secured debt increases stockholder wealth).

17. See Bebchuk \& Fried, Uneasy Case 1, supra note 5 (challenging the idea that in bankruptcy a secured creditor should be entitled to his full claim before any payments are made to unsecured creditors); see also Bebchuk \& Fried, Uneasy Case 2, supra note 5 (reaffirming the claim that priority regarding secured creditors in bankruptcy is basically 
pinned down four categories of nonadjusting creditors: (i) private involuntary creditors, or tort creditors; (ii) governments as holders of tax and regulatory claims; (iii) voluntary creditors with small claims such as customers, employees, and trade creditors; and (iv) prior voluntary creditors extending credit on fixed terms. ${ }^{18}$ For involuntary creditors, nonadjustment may be a combined result of passive ignorance and inability to adjust. On the other hand, for voluntary creditors with small claims, especially trade creditors, the failure to adjust interest rates in each transaction is more likely a rational choice, given the small amount of claims relative to the cost of adjustment.

Nonadjusting creditors, however, are not necessarily hurt by the borrower's inefficient investment decisions. Trade creditors, for example, can charge an interest rate that, on average, fully compensates their risk of loss due to security interests, even if they do not adjust their interest rates in any specific transaction. ${ }^{19}$ Prior voluntary creditors, when properly anticipating the risk caused by subsequent secured debts, will set the interest rate of their loans to take this risk into account. Put differently, the prior voluntary creditors can protect themselves through ex ante adjustments, and in those cases, rational borrowers would issue secured debts as anticipated. ${ }^{20}$ But there are also nonadjusting creditors who will be hurt by the use of security credits with priority. Tort creditors are among the victims, as are the voluntary nonadjusting creditors who do not always deal with the debtor on terms that reflect the risk of security interests and

inefficient).

18. Bebchuk \& Fried, Uneasy Case 1, supra note 5, at 882-91. The presence of nonadjusting creditors, and tort creditors in particular, is widely noted in academic literature. See, e.g., Buckley, supra note 4, at 1406 (stating that secured lending has distributional consequences for tort claimants); John Hudson, The Case Against Secured Lending, 15 INT'L REV. L. \& ECON. 47 (1995) (arguing against secured lending due to its negative effects on credit markets and unsecured creditors); Leebron, supra note 7, at 1568 (discussing the perverse effects of limited liability on tort claimants); LoPucki, supra note 7, at 1893 (noting that tort creditors' unsecured status is involuntarily imposed on them).

19. Bebchuk \& Fried, Uneasy Case 1, supra note 5, at 886-87; Bebchuk \& Fried, Uneasy Case 2, supra note 5, at 1313.

20. Otherwise, prior voluntary creditors will receive a windfall gain. Bebchuk and Fried admit that the prior voluntary creditors can make ex ante adjustments, but they emphasize that this will not stop the usage of security interests to "make the borrower better off by allowing it to 'sell' to the creditor bankruptcy value that would otherwise be enjoyed by these prior nonadjusting creditors." Bebchuk \& Fried, Uneasy Case 1, supra note 5, at 890-91. In this context, the borrower is better off by issuing security debts, but only because it precludes the windfall gain that "would otherwise be enjoyed by" the prior voluntary creditors adjusting the interest rate in advance. $I d$. at 891 . The prior voluntary creditors will not be exploited insofar as they appropriately anticipate the possibility of subsequent secured debts and set the interest rates accordingly. See Scott, Reply, supra note 16 , at 258 . 
that cannot mitigate the risk by diversification, as can the debtor's employees and customers. ${ }^{21}$

Those creditors unhurt by secured debts are essentially not subject to the distributional effects, even if they do not adjust their interest rates per se. Although their existence may help explain the use of secured debts, it should not change the efficiency implications of secured lending. As this paper is concerned mainly about social efficiency, I define nonadjusting creditors in a narrower manner as creditors who, when unsecured, cannot increase interest rates to completely account for the extra risk caused by the attainment of security interests by other creditors. In short, they are the real victims of the distributional effects created by secured lending.

In contrast, an adjusting creditor is able to make such an increase in interest rates. However, adjusting creditors are not perfectly informed either. Professor Triantis distinguishes two types of information imperfections faced by lenders:

(a) information asymmetry related to parameters of payoff distributions as they exist at the time the debt is issued, and $(b)$ the lenders' imperfect control over, and information about, decisions of the firm made between the time the debt is issued and its maturity, which may change the value of these parameters. ${ }^{22}$

The adjusting creditors in this paper, unless stated otherwise, are assumed to have accurate information about the payoff distributions as they exist at the time of debt issuance, but imperfect control over and imperfect information about the borrower's decision between the time of debt issuance and maturity.

\section{Inefficiencies Resulting from the Distributional Effect}

As Professor Carlson pointed out, ${ }^{23}$ the presence of nonadjusting creditors suffering a loss due to the use of secured debts with priority alone is insufficient to challenge the efficiency of secured lending, at least in the Kaldor-Hicks sense, because the gains accrued to the borrower may well offset or even exceed the loss. The comparison between the magnitudes of such gains and losses, however, is inevitably an empirical task, and no decisive conclusion can be expected from theoretical arguments. This said,

21. Bebchuk \& Fried, Uneasy Case 2, supra note 5, at 1313-14. But see Buckley, supra note 4, at 1407-09 (arguing that employees and customers are not likely to be substantially hurt).

22. Triantis, Secured Debt, supra note 4, at 233.

23. See David Gray Carlson, Secured Lending as a Zero-Sum Game, 19 CARDOZO L. REV. 1635, 1665 (1998) ("To the extent that economic discourse concerns itself with the maximization of wealth, it does not concern itself with wealth transfer per se.") 
before meaningful empirical undertakings become possible, theoretical analyses are nonetheless worthwhile in terms of identifying the possible origins of costs and benefits. Hence, in this Part I will first summarize the major efficiency costs opponents raise about the priority of security interests and then evaluate the theories regarding the efficiency benefits of this priority scheme in the next Part.

\section{Costs of Granting Security Interests as a Net Welfare Loss}

Sometimes the borrower will not change its investment decision regardless of whether a secured or unsecured loan is used. ${ }^{24}$ In these situations, the borrower will nonetheless choose secured lending purely to take advantage of the lower interest rate offered by a secured creditor. This security interest clearly does not benefit society by any measure, as neither the probability of investment failure nor the borrower's asset value in case of investment failure would differ were the lending unsecured. However, the use of security interests itself is never free, and the resulting costs, externalized to nonadjusting creditors, becomes a net social welfare loss. ${ }^{25}$ Professors Bebchuk and Fried identified three primary categories of such costs: "(1) 'contracting costs' - including the cost of negotiating and perfecting the security interest; (2) 'enforcement costs' - the costs of policing the collateral; and, perhaps most importantly, (3) 'opportunity costs' - the costs created when the security interest prevents the borrower from pursuing efficient activities." ${ }^{26}$

To this list we may add the increased cost of reorganization when the debtor is insolvent. Because secured creditors have priority, they tend to prefer liquidation, which entails lower risk, even if reorganization may generate greater value to all parties involved as a whole. ${ }^{27}$ Secured creditors also tend to push through a speedy sale to promptly recover their investments at a price high enough to pay off secured credits, but often less

24. See infra Part V Example 5 for an illustration of this situation.

25. For a numeric illustration of such a case of net welfare loss, see Bebchuk \& Fried, Uneasy Case 1, supra note 5, at 896-97.

26. Bebchuk \& Fried, Uneasy Case 1, supra note 5, at 877.

27. Listokin, supra note 2, at 1037, 1047. For a general discussion about secured creditors liquidation preference, see Douglas G. Baird \& Thomas H. Jackson, Corporate Reorganizations and the Treatment of Diverse Ownership Interests: A Comment on Adequate Protection of Secured Creditors in Bankruptcy, 51 U. CHI. L. REV. 97, 106-07 (1984). However, with the increasingly active role of hedge funds in the secured loan market, this long-standing assumption may start to falter. See Douglas Baird \& Rasmussen, supra note 9, at 668-71 (discussing how the incentives of hedge funds differ from those of traditional banks in the case of debtor's bankruptcy as secured lenders). 
than the assets' true worth, ${ }^{28}$ thus resulting in inefficient allocation of assets. Furthermore, secured creditors are "uniquely placed to 'hold up"" the reorganization negotiation to extract excess value because they lose little if the failure of negotiation leads to liquidation. ${ }^{29}$

\section{Increased Debtor Misbehaviors}

Debtors misbehave because their interests are not aligned with their creditors. When free from control, debtors are ready to pursue any activities that make themselves better off at the creditors' expense. This is the well-known agency problem of debt financing. ${ }^{30}$

The most frequently discussed form of debtor misbehavior in the law and economics literature on security interests is "overinvestment," i.e., the debtor's preference for higher-risk and higher-return projects even though these projects harm creditors by a larger margin than they benefit the debtor. ${ }^{31}$ This preference stems from the fact that the debtor will capture all of the additional return if the risky projects succeed while the creditors will bear the costs if they fail. ${ }^{32}$ Inspired by the overinvesting incentive, the debtor may take on a project with a negative net present value (NPV) in the absolute sense, or, roughly speaking, a project having an expected value lower than its cost. Alternatively, the undertaken project can also be of a

28. Douglas G. Baird, ElEMENTS OF BANKRUPTCY 228 (5th ed. 2010).

29. Listokin, supra note 2, at 1048.

30. In discussing the agency problem of debt financing, I assume, as most writers on security interests do, that the debtor's management full-heartedly serves its shareholders' interests. In other words, the agency problem of equity financing is assumed away. By and large, the literature on secured lending is not concerned with the effects of security interests on equity financing. Instead, perhaps implicitly, the agency cost of equity financing is taken as the precondition for the very existence of debt financing. The only notable exception, to my knowledge, is Professor Adler, who believes that the efficiency of secured lending comes from the value it may add to the debtor's non-management equity investors. See Adler, Equity-Agency Solution, supra note 4, at 74-75. Professor Levmore also mentioned the potential positive influence of secured credit on equity holders in an earlier article. See Levmore, supra note 4, at 68-71 (discussing the monitoring value of secured credit).

31. I use this term following Bebchuk \& Fried, Uneasy Case 1, supra note 5, at 874. Some law and economics scholars use the term "risk-alteration" instead. See, e.g., Levmore, supra note 4, at 52 (using the term "risk-alteration" to describe such behavior). In financial literature, the term "asset substitution" is more often used to refer to roughly the same phenomenon. Strictly speaking, however, asset substitution may be understood as a particular type of overinvestment. See Buckley, supra note 4, at 1438 (describing asset substitution as the acquiring of a new, riskier asset by selling older, less risky assets).

32. The overinvestment problem was first explained in Michael C. Jensen \& William H. Meckling, Theory of the Firm: Managerial Behavior, Agency Costs and Ownership Structure, 3 J. FIN. ECON. 305, 333-43 (1976). For a formal discussion, see Richard C. Green \& Eli Talmor, Asset Substitution and the Agency Costs of Debt Financing, $10 \mathrm{~J}$. BANKING \& FIN. 391 (1986). 
negative NPV in a marginal sense, i.e., a project with a lower expected value net of its cost given the availability of more socially efficient projects. ${ }^{33}$ The quintessence of overinvestment is the discrepancy between the social and the debtor's private interests given the possibility to redistribute wealth from creditors to the debtor. This problem has been widely recognized by law scholars and illustrations abound in legal writings. ${ }^{34}$

Another form of misbehavior that the debtor may engage in is "asset dilution," which consists of taking assets out of the reach of creditors if the debtor eventually goes bankrupt. Asset dilution can be socially inefficient when it reduces the debtor's value more than the gains it passes on to the debtor's shareholders. The debtor's incentive to remove assets originates, again, from the prospect that the creditors will bear the costs of such removal when the debtor fails. ${ }^{35}$

Debtor misbehavior can be exacerbated in two ways when a secured debt is used in the presence of nonadjusting creditors. First, secured creditors tend to charge lower interest rates. But if unsecured creditors adjust interest rates to offset the worsened repayment prospect of their loans, the debtor's overall cost of borrowing remains unchanged, so its incentive to borrow will not vary on the whole. However, since nonadjusting creditors do not make such adjustment after the issuance of a secured debt, the total cost of borrowing declines as the debtor borrows on a secured basis. Therefore, compared with a world disallowing secured lending, the debtor will be more willing to borrow if secured lending is an option. Expanded reliance on debt financing, in turn, intensifies the debtor's incentive to overinvest. ${ }^{36}$

Second, although debtor misbehaviors can be restricted by creditors' monitoring, and cost-effective monitoring reduces the agency costs

33. Bezalel Gavish \& Avner Kalay, On the Asset Substitution Problem, 18 J. FIn. \& QuANTITATIVE ANALYSIS 21, 27 n.9 (1983).

34. See, e.g., Buckley, supra note 4, at 1426-29 (illustrating that a firm which has issued debt has an incentive to choose a riskier investment because in assessing the value of the investment the firm considers the return on the investment minus the debt to be repaid); Kanda \& Levmore, supra note 4, at 2108-11 (illustrating how debt alters the expected return of an investment and how this creates an incentive to invest in riskier investments); Bebchuk \& Fried, Uneasy Case 1, supra note 5, at 873-75 (demonstrating how debt impacts the calculation for expected return).

35. For a numerical example of asset dilution, see Bebchuk \& Fried, Uneasy Case 1, supra note 5, at 874-75. A third form of debtor misbehavior is "underinvestment." Underinvestment bearing on security interests is also explored extensively, though perhaps incompletely, in the field of law and economics. The thrust of this relationship becomes clearer when we better understand the connection between the priority of security interests and the overinvestment problem. See infra Part VI A (discussing underinvestment).

36. See infra Part IV.B. for details. 
involved in debt financing, secured creditors will have less incentive to monitor because they are insulated from the negative effects of debtor misbehaviors insofar as the value of the collateral does not drop below the amount of their loans. ${ }^{37}$ In a competitive debt market absent nonadjusting creditors, reduced monitoring by secured creditors may well implicate intensified monitoring efforts by unsecured creditors. The debtor then will demand an optimal level of monitoring as it bears the agency costs to the full extent. Given the different incentives in monitoring brought about by secured and unsecured debts, and the uneven monitoring capabilities among creditors, the debtor should award security interests selectively to encourage optimal monitoring, thus minimizing the agency costs it is expected to bear. Indeed, this idea is squarely embodied in the early efforts of identifying the efficiency of secured debts. ${ }^{38}$

When the unsecured creditors do not adjust their monitoring efforts or interest rates as a consequence of the debtor's grant of security interests, however, the issuance of secured debts simply decreases the total monitoring efforts by all creditors, and the probability of debtor

37. Most commentators agree that security interests disincentivize creditors to monitor debtor misbehaviors when their loans are sufficiently secured. See Adler, Equity-Agency Solution, supra note 4 , at 89 (noting that because adequately secured creditors will receive full repayment despite firm mismanagement, secured creditors have no incentive to monitor); Bebchuk \& Fried, Uneasy Case 2, supra note 5, at 1317-18 (stating that an adequately secured creditor will have less incentive to engage in enforcement activity or adopt efficient covenants); Buckley, supra note 4, at 1440, 1443 (stating that secured creditors have little incentive to affirmatively monitor a debtor); Triantis, Secured Debt, supra note 4, at 244 (stating that secured creditors have an incentive to monitor assets acting as security and reduce any other monitoring). But Professor Levmore posits that secured creditors are nevertheless likely to engage in asset-specific monitoring. See Levmore, supra note 4, at 55-59 (stating that the monitoring of an asset by a secured creditor may act to effectively monitor the debtor as a whole). For critiques on Levmore's theory, see Buckley, supra note 4, at 1442-45 (suggesting its empirical weakness in addition to the theoretical difficulties); Schwartz, Continuing Puzzle, supra note 3, at 1056-59 (discussing its theoretical inconsistency).

38. See Jackson \& Kronman, supra note 4, at 1143 (stating that security acts as protection against claims from competing creditors); see also Triantis, Secured Debt, supra note 4, at 244-45 (incorporating Levmore's theory of asset-specific monitoring). The monitoring efficiency argument for secured debts, however, does not bear out empirically. See Buckley, supra note 4, at 1441-44 (suggesting that optimal efficiency would require either the largest creditors or the creditors most capable of monitoring be unsecured, which contradicts reality where banks are typically secured creditors); Schwartz, Security Interests, supra note 3, at 11-14 (stating that because short-term debt requires less monitoring, one would expect to see unsecured short-term debt, yet the large amount of secured short-term debt by retailers contradicts this). In this paper, I do not attempt to assess the validity of the monitoring cost justification for security interests, as my focus on cases with the existence of nonadjusting creditors contradicts the very assumption underlying this justification: unsecured creditors adjusting interest rates to reflect their increased monitoring costs in the wake of the issuance of secured debts. 
misbehaviors rises as a result. The reduced monitoring can, as Professors Bebchuk and Fried have noted, take the form of reduced use of financial covenants and reduced effort in enforcing the covenants that do appear in secured loan agreements. ${ }^{39}$ An important function of loan covenants is to simplify monitoring by creditors in that a breach of covenants may signal potential debtor misbehaviors that can be hard to observe otherwise. Thus, enforcing these covenants as agreed is a primary approach to control the debtor's opportunistic actions after debt issuance. ${ }^{40}$ Fully secured creditors are insufficiently incentivized to incorporate rigorous covenants in their loan agreements, and perhaps more importantly, to diligently enforce the ones that do get incorporated since the priority they enjoy perfectly shields them from the negative effects of the elevated probability of debtor misbehaviors.

\section{Lowered Precaution Against Tort Liabilities}

The third category of inefficiency accompanying the distributional effect of security interests under the current priority scheme is that the borrower is likely to take less precaution against the potential tort liabilities resulting from its operation. Though not inherently a form of agency costs of debt financing, insufficient precaution against harm to third parties nevertheless represents a loss to society.

When the debt is unsecured, the creditor will charge the debtor a higher interest rate to the extent that it anticipates future tort claims will dilute the creditor's share in the borrower's bankruptcy estate, thus lowering the value of its loan. Through this mechanism, the creditor forces the debtor to internalize more of the costs of potential accidents if the latter fails to take sufficient precautions. A secured debt with full priority,

39. Professors Bebchuk and Fried seem to agree that reduced use and enforcement of loan covenants reflect secured creditors' dampened enthusiasm to monitor the debtor, because the authors discussed these two issues in the same subsection in their 1997. Bebchuk \& Fried, Uneasy Case 2, supra note 5, at 1315-18; see also Bebchuk \& Fried, Uneasy Case 1, supra note 5, at 897-98, 900-902 (also discussing the lack of interest in using and enforcing covenants in the same subsection of the article, titled "Efficiency Costs of Full Priority").

40. Some covenants specifically require information such as financial statements and accounting techniques from the debtor, thus facilitating the detection of misbehaviors. Others forbid certain activities that may link to debtor misbehaviors, such as borrowing new debts or paying dividends, so the breach of these covenants may signal potential misbehaviors. For a detailed analysis of the economic functions of financial covenants, see Clifford W. Smith, Jr. \& Jerold B. Warner, On Financial Contracting: An Analysis of Bond Covenants, 7 J. FIN. ECON. 117 (1979). For an explanation of the legal issues involved in drafting and using financial covenants, see Robert M. Lloyd, Financial Covenants in Commercial Loan Documentation: Uses and Limitations, 58 TENN. L. Rev. 335 (1991). 
however, safeguards the creditor against the dilution of tort claims, thereby eliminating the need to raise the interest rate. Consequently, it is easier for the debtor to externalize the costs of potential harm to tort victims, and its incentive to take precautions diminishes. ${ }^{41}$ What follows will be an increase in value of unsafe firms, which in turn results in an inefficient allocation of capital to these firms and a greater number of accidents. ${ }^{42}$

With all these inefficiencies, the priority status held by secured creditors in bankruptcy indeed becomes an uneasy award unless there are enough counteracting benefits. The remainder of this Article explores these benefits.

\section{A REVIEW OF THE THEORIES ON THE EFFICIENCY OF SECURED LENDING}

Explorations for its efficiency benefits have long been at the center of scholarly research on security lending. However, the uneasy case presented by Professors Bebchuk and Fried specifically targets the priority of secured claims with nonadjusting creditors on the scene. To make the case less "uneasy,", efficiency benefits of secured lending must: (i) stem from the priority effect, and (ii) exist even in the presence of nonadjusting creditors. As discussed below, most efficiency arguments for secured lending are either misleading or do not meet these two criteria. ${ }^{43}$

\section{A. Signaling Efficiency}

Arguments for the efficiency of secured lending can be divided roughly into two groups - those based on its function of mitigating information asymmetry and those emphasizing its role in tackling with agency problems. ${ }^{44}$ Whereas the focus of this paper, as well as that of

41. Bebchuk \& Fried, Uneasy Case 2, supra note 5, at 1319; Bebchuk \& Fried, Uneasy Case 1, supra note 5, at 898-900. For the more general discussion of suboptimal investment as a result of limited liability, see Henry Hansmann \& Reinier Kraakman, Toward Unlimited Shareholder Liability for Corporate Torts, 100 YALE L.J. 1879, at 1909-16 (1991).

42. Buckley, supra note 4, at 1417-18.

43. This Part does not address the efficiency of secured lending in overcoming underinvestment; this seems to be the consensus, as even Professors Bebchuk and Fried did not dispute it. Alleviating the uneasiness of the priority enjoyed by secured creditors, therefore, requires the identification of some other benefits. But the underinvestment problems will be discussed later in this paper, which argues that even this merit of secured lending is actually subject to the "paradox of security lending." See Part VI A infra.

44. To be more accurate, the former group focuses on the "information asymmetry related to parameters of payoff distributions as they exist at the time the debt is issued," while the latter focuses on the difficulty in controlling debtor misbehaviors after the debt is issued but before its maturity. Triantis, Secured Debt, supra note 4, at 233. 
Professor Bebchuk and Fried's, is on the latter, ${ }^{45} \mathrm{I}$ will briefly assess the signaling efficiency justification presented by the former group. ${ }^{46}$

The signaling efficiency theory assumes that the lenders have imperfect information about the risk of the debtor's projects, but are aware of the possibility that firms with low-quality projects will borrow at interest rates not reflecting the risk of these projects if the interest rates are set based on relatively high-quality projects. So lenders will, when lacking information about the quality of particular projects, suppose the average project quality to be low and charge higher interest rates accordingly. Firms with projects of higher quality than the market average, hoping for better interest rates, will have an incentive to signal to the market their relative status. ${ }^{47}$

A security interest serves as a credible signal if the borrower's cost of awarding it varies inversely with the quality of its investment, making firms with low-quality projects less inclined to send the same signal. The proponents of this theory submit that it is indeed the case. ${ }^{48}$

Four attributes of secured debts are thought to be relevant in this respect. First, a security interest in a specific asset reduces the future alienability of the asset by the debtor because, as a general rule, the transfer of collateral passes title to the transferee subject to the perfected security interest unless the transfer is made in the ordinary course of business. As a result, the debtor, after issuance of secured debts, constrains its ability to capitalize on riskier investment opportunities by substituting the collateral. All else being equal, this constraint is more costly for firms with riskier and less profitable investments.

Second, if the collateral is a piece of a firm-specific asset with substantial idiosyncratic value to the debtor, loss of such value resulting

45. The limited empirical study on the efficiency of secured lending finds little support for the information-asymmetry theory. See Michael J. Barclay \& Clifford W. Smith, Jr., The Priority Structure of Corporate Liabilities, 50 J. Fin. 899, 909 (1995) (using firms' abnormal future earnings to measure empirically the value of signaling models in explaining priority structure, and concluding that they have little value in explaining the informationasymmetry hypothesis).

46. Professor Buckley proposed another theory regarding information asymmetry: the screening efficiency of secured debts. See Buckley, supra note 4, at 1421-26 (reasoning that the grant of security interests reduces lenders' net screening costs). Interesting as it is, the specific mechanism underlying the screening efficiency is not necessarily clear. See Part VI.B, infra for a short discussion.

47. Schwartz, Security Interests, supra note 3, at 14-15 (discussing secured debt as a signal of project quality).

48. The description in the following paragraphs is based on Triantis, Secured Debt, supra note 4, at 247, 253-55 (discussing secured debt and its use as a constraint on wealth distribution and as a signal). See also Schwartz, Security Interests, supra note 3, at 15 (discussing the theory of signaling and its consequences). 
from the enforcement of security interest amounts to a significant threat to the debtor. The greater the probability of default, the larger the expected cost of losing the idiosyncratic value. Therefore, low-quality debtors would be less willing to grant security interests in firm-specific assets.

Third, in the event of default, the repossessory right held by secured creditors usually enables them to quickly seize the collateral. Since the equity value of a financially distressed firm depends on the probability of recovery, which wanes with the shortened time span of debt enforcement by secured creditors, the issuance of secured debts becomes more expensive for lower-quality borrowers, all else being equal.

Finally, given their ability to seize collateral and thereby impede the debtor's operations, secured creditors can sometimes exert substantial influence on the debtor's business decisions. The cost of the expected interference, however, is believed to vary inversely with firm quality.

Professor Schwartz criticizes the signaling theory for its lack of exactness, stability, and the possibility of dissipative signaling. ${ }^{49}$ But even if the arguments made by its advocates are sufficiently persuasive, the effectiveness of signaling seems to depend on, as Professors Bebchuk and Fried call it, the priority-independent benefits of secured debt, so the signaling efficiency theory does not meet the first criterion set above. Professor Adler asserts that a security interest is both a property interest and a priority interest. ${ }^{50}$ To that end, it appears that the presumed signaling function of a security interest derives primarily from its characteristics as a property interest. The curtailed alienability is obviously a consequence of the in rem nature of property interests. ${ }^{51}$ The repossessory right is also likely to find its kinship from property interests, such as the right of eviction traditionally held by landlords. ${ }^{52}$ To the extent that the secured

49. See Alan Schwartz, Taking the Analysis of Security Seriously, 80 VA. L. REV. 2073, 2084-85 (1994) (discussing asymmetric information and signaling); Schwartz, Security Interests, supra note 3, at 17-21 (explaining why the signaling theory has serious difficulties); see also Alan Schwartz, A Theory of Loan Priorities, 18 J. LEGAL STUD. 209, 244-47 (1989) (criticizing the faults of the signaling theory, such as failing to address the problem of mimicking, which refers to the ability of "bad" debtors to "mimic" the quality of "good" debtors by offering comparable security interests).

50. Barry E. Adler, Secured Credit Contracts, in The New Palgrave Dictionary of ECONOMICS AND THE LAW 405, 405 (Peter Newman ed., 1998) [hereinafter Adler, Secured Credit] (stating that a security interest is a priority interest that allows secured loans to be repaid head of other obligations, and also a property interest attached to the collateral).

51. For the in rem nature of property interests, see Thomas W. Merrill \& Henry E. Smith, What Happened to Property in Law and Economics?, 111 YALE L.J. 357, 360-66 (2001) (discussing the traditional conception of property rights).

52. See William B. Stoebuck \& Dale A. Whitman, The Law of Property $§ 6.80$ (3d ed. 2000) (discussing eviction by self-help). Admittedly, this kind of self-help right substantially diminished even with respect to property interests. However, the key point 
creditor's leverage comes from this repossessory right, it might as well be understood as a byproduct of the proprietary effects of security interests. ${ }^{53}$

here is that the signaling effect of a security interest, if any, does not rely on its priority.

53. Professor Listokin suggests that the effectiveness of foreclosure as a deterrence to debtor misbehaviors depends critically on the priority of security. But for the priority enjoyed by secured creditors in bankruptcy, the foreclosure threat would not be credible when the debtor counter threatens to file for bankruptcy. See Listokin, supra note 2, at 1050 n.39 (noting that secured creditors will be reluctant to foreclose when the secured creditor does not enjoy priority but that secured creditors who do enjoy priority would not be so loath to do so).

First of all, Listokin's reasoning apparently assumes that the debtor's counterthreat is credible, which, given the costs of bankruptcy on the debtor, may not be true. But even if we are ready to accept this assumption, his position is not convincing as the priority of security interests, if it does anything, probably undermines, rather than advances, the credibility of the foreclosure threat. It is crucial to note that the credibility of this threat depends on whether the secured creditor's expected payoff when it carries out the threat is greater than its expected payoff when it does not, given, respectively, the existence or nonexistence of priority. Even in a world without priority, the secured creditor's threat is credible as long as it expects to be better off by carrying out its threat, and the same condition holds for the threat to be credible in a world with priority. It does not matter, however, whether the secured creditor would recover more should it enjoy the priority. Judging by this standard, it seems that a secured creditor entitled to priority will, at most, be indifferent as to whether to carry out its threat and trigger the bankruptcy filing immediately because in either case it will be fully repaid insofar as it is not undersecured. Indeed, considering the imperfect protections provided to secured claims under the bankruptcy law, the secured creditor may even be worse-off by trapping itself into the bankruptcy process (for the imperfections of bankruptcy protection of secured claims, see Schwarcz, supra note 4 , at 456-57 (pointing to the automatic stay, the risk that collateral may be substituted, and the fact that an oversecured lender is not always entitled to the full value of the collateral cushion). On the other hand, without priority, a secured creditor will still proceed to foreclose if the resulting immediate bankruptcy is expected to provide better financial recovery than what it would otherwise receive through later debt collection. Interestingly, when the secured creditor, in this context, believes that the debtor attempts to misbehave, perhaps it is bound to take action immediately since debtor misbehaviors by definition will reduce the amount of assets available to creditors, from which the secured creditor without priority will be repaid proportionately. The secured creditor can hardly expect more value if it tolerates the misbehavior. Foreclosure thus seems to be a dominant strategy for the secured creditor without priority. Absent the shield of priority, the secured creditor is exposed to the danger of debtor's wealth-redistributing actions much like unsecured creditors. Therefore, the secured creditor should be more serious at wielding any power it has to deter the debtor's opportunism in a world where priority does not exist.

This, however, leads us to a more fundamental question about why a fully secured creditor entitled to priority will ever want to control debtor misbehaviors as far as these misbehaviors do not impair the value of collateral. If secured creditors with priority even "do not in fact appear to do much actual monitoring of collateral value," then it is unrealistic to anticipate them to use whatever leverage they may have to prevent the debtor from misbehaving. See Buckley supra note 4, at 1443. After all, they will be repaid from the collateral value regardless of the debtor's behaviors. I will further discuss this issue below, in connection with the monitoring efficiency and leverage efficiency arguments for security interests. See Part III.B \& C infra. 
As for the loss of idiosyncratic value, it is clear that priority does not matter, either. This kind of loss occurs whenever the collateral is sold, but has nothing to do with how the sale proceeds are divided among the creditors.

\section{B. Monitoring Efficiency}

The monitoring efficiency argument, as well as the leverage and the overinvestment prevention arguments discussed below, focus on the potential of secured lending to lessen the agency costs of debt financing. Effectively, they all stress the advantage of using secured lending to constrain debtor misbehaviors at a lower cost.

The presumed monitoring efficiency of secured debts comes from the differing incentives to monitor the borrower of secured versus unsecured creditors. One line of reasoning, sometimes referred to as the "relative skills theory, ${ }^{, 54}$ starts by noting that secured lenders are less incentivized to monitor the debtor since they are free from the risk of loss insofar as the value of their collateral exceeds the value of their loan. On the other hand, when advised of the existence of secured credits, unsecured lenders will increase their monitoring efforts as they are now subject to even higher risk of loss in the event that the debtor misbehaves. In light of such an incentive difference, the borrower will be better off if it issues security interests in a way that reduces the overall agency costs in a competitive debt market. This can be achieved by granting security interests to lenders with relatively higher monitoring costs to muffle their willingness to monitor, thus channeling the monitoring responsibility to those more skilled monitors. ${ }^{55}$

Another version of the monitoring theory emphasizes the possibly disparate nature of asset-specific monitoring vis-à-vis general monitoring. It insists that secured creditors are encouraged to conduct asset-specific monitoring of debtor misbehaviors concerning the collateral, while unsecured creditors will be led to policing other agency problems. When different creditors have comparative advantages in different kinds of monitoring, security interests enable the parties to exploit economies of scale and specialization of labor by efficient allocation of monitoring tasks among creditors. $^{56}$ Therefore, this version of monitoring efficiency

54. Buckley, supra note 4, at 1441.

55. See Jackson \& Kronman, supra note 4, at 1159-60 (discussing the connections between secured lending and monitoring costs); see also Triantis, Secured Debt, supra note 4 , at 245 (describing how an optimal collective-monitoring strategy by restructuring the financial incentives for monitoring).

56. See Levmore, supra note 4, at 55-57 (discussing secured lending as a solution to 
argument is called the "specialization theory." 57

The logic underpinning the relative skills theory seems sound. As the lower-cost monitor undertakes more intensive monitoring (saving the efforts of the higher-cost monitor), the total monitoring costs decline. However, the resulting degree of monitoring is still not optimal, given the externalities associated with monitoring in multiple-creditor cases. The critics' major attack against this theory lies in its failure to bear out empirically. For instance, banks are more frequently secured than trade creditors, notwithstanding the fact that the latter category is unlikely to be a more sophisticated monitor than the former. ${ }^{58}$ Similarly, suppliers to complex businesses are not secured any more frequently than suppliers to simple businesses in spite of the relative convenience for the latter to monitor. $^{59}$ It is worth noting that secured lending might be a rather primitive device for allocating monitoring responsibilities among creditors with varying skills in policing debtor misbehaviors. Indeed, it works almost like an on-and-off switch to signal when the secured creditor has an adequate equity cushion in the collateral. ${ }^{60}$

The specialization theory, on the other hand, relies on the dubious validity of more restrictive assumptions. One necessary condition for such specialized monitoring appears to say that a creditor will be more motivated to monitor particular assets when those assets are used to secure that creditor's loan. But the opposite situation may be equally, if not more, plausible. The property nature of security interests dulls the creditor's interest in monitoring because the secured creditor's rights in a particular piece of collateral are not compromised, regardless of whether the debtor engages in asset substitution or asset removal. In addition, when a creditor does have a comparative advantage in monitoring certain kinds of assets, it should be no less motivated to monitor these assets as an unsecured creditor than as a secured one, and its monitoring is likely to be part of the equilibrium outcome of a non-cooperative game.

As Professor Schwartz has noted, only one monitor can exist in a stable equilibrium, regardless of whether a secured debt is used, when one creditor's monitoring is sufficient to prevent debtor misbehaviors related to particular assets. ${ }^{61}$ Since there is a creditor assumed to be better at such

the freeriding problem); see also Triantis, Secured Debt, supra note 4, at 244-45 (discussing the effect of a security agreement on monitoring costs).

57. Buckley, supra note 4, at 1442.

58. Id. at 1441-42.

59. Schwartz, Security Interests, supra note 3, at $11 \mathrm{n} .28$.

60. In theory, the parties can leave the secured creditor's loan only partly secured, and adjust the ratio of the secured and unsecured portions to fine-tune the creditors' monitoring incentive but in practice, the cost of doing so may well outweigh its benefit.

61. See Schwartz, Continuing Puzzle, supra note 3, at 1055-58 (examining Levmore's 
monitoring, the equilibrium that elicits its monitoring is probably the focal point of the game. Therefore, monitoring, if it ever occurs, will plausibly be conducted by that creditor. In other words, specialized monitoring is always possible, whether the debt is secured or not.

Even if monitoring efficiency does exist, under either the relative skills theory or the specialization theory, when all creditors make adjustments as a result of the issuance of secured debts, this efficiency will not arise in the presence of nonadjusting creditors. One creditor's monitoring would lower the probability of debtor misbehavior, which is a benefit shared by all creditors of the same debtor, but the costs of monitoring are borne solely by the creditor that monitors. Because of the free rider problem, creditor monitoring is suboptimal in general. As security dampens the secured creditor's monitoring incentive further, secured lending will exacerbate the under-monitoring problem if unsecured creditors do not strengthen their monitoring accordingly. This implies that, with the presence of nonadjusting creditors, secured debts will not improve the overall monitoring efficiency except when it is the nonadjusting creditors that are secured, which appears unlikely without compulsory legal intervention. ${ }^{62}$ Therefore, monitoring efficiency cannot pass the second criteria mentioned above (a benefit existing even without the presence of nonadjusting creditors) for a less uneasy case of secured credit.

\section{Leverage Efficiency}

A third argument for the efficiency of secured lending looks at the leverage held by secured creditors to restrict potential debtor misbehaviors. According to Professor Scott, "the primary value of collateral is ... the strong negotiating position that it gives to the secured creditor," function of secured credit is conceived within the industry as enabling the creditor to influence debtor actions prior to the onset of business failure." ${ }^{64}$ This presumed effect of security on curbing debtor misbehaviors, however, relies on at least two integrated conditions: $(i)$ secured lending increases the creditor's leverage and (ii) the secured creditor is properly motivated to use its leverage.

Does secured lending increase the creditor's leverage over the debtor's discretion in investment strategy? The advocates of the leverage theory

theory that two creditors monitoring a debtor's assets creates added costs for the debtor, and thus the debtor will secure a single efficient monitor to minimize credit costs).

62. If nonadjusting creditors were secured, the distributional effect of security would not be an issue in the first place.

63. Scott, Relational Theory, supra note 4, at 945.

64. Id. at 950 . 
believe that "the main foundation of the secured creditor's leverage is the differential between the collateral's value to the borrower and the amount that the lender would credit on the loan if the collateral were liquidated under the security agreement or mortgage." ${ }^{65}$ In other words, the secured creditor's ability to liquidate the debtor's assets at a value lower than what they are worth to the debtor imposes constraints on the debtor's opportunism that may trigger such liquidation. But is this ability unique to secured creditors? Are unsecured creditors able and willing to do so as well ${ }^{66}$ A creditor tends to sell assets at prices less than their value to the debtor for two reasons when doing so is cost-justifiable.

First, these assets generate value specific to the debtor so that no other market participants can enjoy such value. Second, although the assets can be sold at a higher price, doing so does not give the creditor any additional benefit surpassing the cost. The first reason seems applicable to secured and unsecured creditors alike. If we believe that the assets are sold at lower prices for the second reason, however, secured creditors may have different incentives than unsecured creditors to pursue this kind of sale. When the debtor is insolvent, ${ }^{67}$ an adequately secured creditor will not realize any gain by selling the collateral at a higher price than what is necessary to recover its loan, while an unsecured creditor will benefit, according to its share in the total unsecured bankruptcy claims, from any incremental increase in the sale price of the debtor's assets. ${ }^{68}$ Therefore, other things being equal, a fully secured creditor is more likely to liquidate the debtor's assets at low prices, if it does conduct such liquidation at all.

In addition, relying on its right to foreclose, a secured creditor can make the liquidation less costly. In particular, Professor Scott emphasizes that the foreclosure right precludes the necessity of verifying the debtor's inefficient investment decision to the court, which can be extremely hard. ${ }^{69}$

65. Mann, supra note 4 , at 665 .

66. Professor Buckley suspects that secured creditor's leverage is not substantially different from an unsecured creditor. Buckley, supra note 4, at 1445-46.

67. If the debtor is not insolvent, secured and unsecured creditors should have similar incentives to liquidate the debtor's assets to recover debts because, in this situation, all creditors, whether secured or not, are supposed to get fully repaid.

68. If the collateral is insufficient to pay off a secured creditor's bankruptcy claims, the creditor will have a strong incentive to push up the price of collateral to recover its loan and to act like an unsecured creditor in tackling the debtor's other assets.

69. Robert E. Scott, The Truth about Secured Financing, 82 CORNELl L. Rev. 1436, 1451 (1997). It should be noted, however, that the secured creditor's right to repossess and foreclose after default is not unlimited. As the most important limit on this right, self-help repossession will be denied for breach of the peace (U.C.C. \$9-609), in which case the secured creditor will not be allowed to bypass the formal court procedures. For a detailed discussion of the "breach of the peace" limit, see LoPucki \& Warren, supra note 1, at 47-52.

Moreover, Professor Buckley suspects that secured creditors do not have an unequivocal 
All these seem to suggest that a security interest does give a creditor some unique leverage over the debtor.

But the additional leverage possessed by secured creditors does not necessarily imply that they will be motivated to use such leverage. As noted above, secured creditors become less eager to monitor debtor misbehaviors, which inevitably means that they are less prone to deter these misbehaviors, whatever leverage they may have. Fully secured creditors can comfortably rely on the equity cushion, and even when inadequately secured, the creditors' incentive to monitor will shrink to the extent they are secured, in that additional monitoring will not have as much benefit as if they were completely unsecured. ${ }^{70}$

Professor Scott did record some evidence that secured creditors routinely monitor the debtor's business affairs. ${ }^{71}$ What needs to be proved, however, is that the same creditors would not have engaged in monitoring more, or at least equally, diligently were they unsecured. Otherwise, as Professor Buckley correctly noted, any cost savings associated with the additional leverage held by secured creditors "would probably be offset by the inefficiencies that arise when a major lender has a reduced incentive to monitor." 72 For this counterfactual, however, the advocates of the leverage theory have not provided any disproof. ${ }^{73}$

advantage in enforcing their loans as unsecured lenders may also bargain for the right to send in a receiver on default. See Buckley, supra note 4, at 1446.

70. Suppose that the amount of a certain lender's loan is L, of which $1-\mathrm{a} \%$ is secured $(0$ $<\mathrm{a}<100$ ), and that the amount of the borrower's other unsecured debt is C. Then every unit of monitoring will increase this lender's loan recovery by a $\mathrm{L} /(\mathrm{a} \% \mathrm{~L}+\mathrm{C})$ of the increase in the debtor's asset value resulting from this last unit of monitoring. But if the creditor were unsecured, all else being equal, every additional unit of monitoring would make it better off by $\mathrm{L} /(\mathrm{L}+\mathrm{C})$ of the increase in the debtor's asset value due to such monitoring. Obviously, extra monitoring can bring the creditor more benefit when it is unsecured for $\mathrm{L} /(\mathrm{L}+\mathrm{C})>\mathrm{a} \% \mathrm{~L} /(\mathrm{a} \% \mathrm{~L}+\mathrm{C})$. In other words, the marginal benefit of monitoring is higher when a creditor is unsecured. Assuming, quite plausibly, that the creditor's marginal cost of monitoring does not vary with the acquisition of security, we should expect a creditor's monitoring efforts to drop when it is secured.

71. Scott, Relational Theory, supra note 4, at 947.

72. Buckley, supra note 4, at 1446.

73. Professor Mann presented a dramatic example in which the secured creditor significantly misunderstood the enforceability of the collateral to underline the necessity for secured creditors to monitor. See Mann, supra note 4, at 640 n.55 (discussing the example of a Dutch bank that loaned money to a fur company and was subsequently prevented by animal rights activists from recovering its loan through the slaughter of beavers pledged as collateral). But such a problem stemming from the nature of the debtor's assets should perplex unsecured creditors as much as secured creditors. In other words, given the special nature of these assets, a creditor might well be better incentivized to monitor when it is unsecured than secured. Mann suggests another reason why secured lenders would be "imprudent to rely predominantly on their ability to obtain forcible repayment through liquidation of the collateral is that they are generally unable to recover the indirect costs that 
In any event, even if we believe that without the presence of nonadjusting creditors, secured lenders will really exert their influence to restrict debtor misbehaviors, so that the aggregate amount of agency costs goes down, the leverage theory fails to explain why rational secured creditors will still be interested in constraining debtor misbehaviors, rather than making profits on these misbehaviors, when nonadjusting creditors do appear. ${ }^{74}$ For example, a creditor will happily finance the $\$ 500$ cost of a project with a $10 \%$ chance of yielding $\$ 3,000$ and a $90 \%$ chance of yielding $\$ 0$ by taking a security interest on the debtor's $\$ 800$ safe assets if the debtor, subject to a tort liability of $\$ 1,000$, agrees to share the gains from this inefficient investment with the creditor. Consequently, the leverage theory is unlikely to establish the efficiency of secured lending in the presence of nonadjusting creditors.

\section{Controlling Overinvestment}

The last important argument for the efficiency of secured lending centers on the overinvestment problem. Three mechanisms have been suggested to control either the debtor's ability or its incentive to overinvest.

\section{Disabling Asset Substitution}

As security interests run with the collateral when it is transferred without the secured lender's permission, the pledged assets become less prone to asset substitution. Also, secured creditors' repossessory right allows for timely and less costly action to default. These features of security interests are considered to constrain the borrower's ability to overinvest through asset substitution. ${ }^{75}$ But this perceived function of secured debt apparently has nothing to do with its priority status. ${ }^{76}$

they incur when monitoring a problem loan." $I d$. But this fits squarely as a reason for curtailed, rather than enhanced, monitoring incentives held by secured creditors.

74. Given the existence of nonadjusting creditors, expecting a secured creditor to use its leverage and control debtor misbehaviors essentially counts on a free riding structure to boost efficiency. As Professor Buckley noted more than two decades ago, the question of "who monitors the monitor" will loom up in any arrangement based on free riding. See Buckley, supra note 4, at 1442-43.

75. Clifford W. Smith, Jr. \& Jerold B. Warner, Bankruptcy, Secured Debt, and Optimal Capital Structure: Comment, 34 J. FIN. 247, 250 (1979).

76. See supra notes 50-Error! Bookmark not defined. and accompanying text (explaining the relation with priority status). 


\section{Precluding Subsequent Borrowing to Finance Risky Projects}

Granting security interests to earlier lenders, it is argued, can limit the debtor's ability to finance subsequent overinvestment based on the belief that the later lender will only agree to advance credit at an interest rate so high as to render the risky project unattractive to the debtor. ${ }^{77}$ In other words, the previously issued secured debt forces subsequent creditors to take into account the risk of inefficient projects and to adjust the cost of capital appropriately.

This efficiency rationale for secured lending, however, seems less convincing if the earlier lender is well informed and has full flexibility to adjust its interest rate. No matter whether it lends secured at a lower interest rate or unsecured at a higher interest rate, the cost of overinvestment will always fall on the debtor, given that the subsequent lender is also an adjusting creditor. Therefore, this second mechanism of overinvestment control inevitably rests on the relaxation of one assumption initially made by Professor Schwartz to introduce the "puzzle of secured debt" so that the earlier creditors cannot "calculate risks of default reasonably precisely." 78 In other words, they must be nonadjusting creditors. But if these lenders were unable to adjust their interest rates, the rational debtor would be induced to borrow unsecured to externalize the cost of overinvestment, unless it was impossible to do so in the debtor's early life. In other words, this second mechanism will become irrelevant if the debtor can borrow unsecured loans from adjusting creditors, and it will be inconsistent with the debtor's borrowing incentive if unsecured loans can be obtained from nonadjusting creditors.

Consequently, such a use of secured debts to constrain overinvestment only works in a limited situation where the borrower cannot acquire unsecured financing from either adjusting or nonadjusting lenders. In fact, some of its advocates do believe that the priority awarded to earlier lenders is necessary for loans made early in the debtor's life. ${ }^{79}$ Yet if a security

77. Adler, Secured Credit, supra note 50, at 406; see also George G. Triantis, A FreeCash-Flow Theory of Secured Debt and Creditor Priorities, 80 VA. L. REv. 2155, 2163 (1994) [hereinafter Triantis, Free-Cash-Flow] (illustrating a tradeoff between first-in-time and later-in-time priority rules).

78. See supra note 14 (discussing four assumptions made by Professor Schwartz).

79. See Kanda \& Levmore, supra note 4, at 2113 n.25 and accompanying text (illustrating a problem in which the interest rate that will satisfy creditors must increase indefinitely as conservative debtors continue to drop out of the market in the face of rising interest rates). Insisting that secured credit is a source of needed liquidity to debtors but not enumerating why such liquidity is impossible to be acquired through unsecured borrowing, Professor Steven Schwarcz might have at the back of his mind a similar concern of market collapse due to information asymmetry. See Schwarcz, supra note 4, at $442 \mathrm{n} .75$ and 
interest with bankruptcy priority is really a precondition for early loans from nonadjusting creditors, then should such priority be abolished, these lenders would not appear at all, and the inefficient externalization of overinvestment costs would not be an issue in the first place. ${ }^{80}$

Moreover, the borrower will only issue secured debts early in their life if the market is filled with lenders unwilling to advance unsecured credits. Indeed, in such a market, without reasonable knowledge about the debtor's expected lifespan, no creditor should ever extend unsecured loans. In this situation, essentially, no creditor will be able to play the role of an effective controller of overinvestment since none can be sure whether it is in the position of a relatively "earlier" or "later" lender. This logical prediction, however, is plainly at odds with the reality, as we do see unsecured lending, but not secured debts, crammed in borrowers' early lives. ${ }^{81}$

Even if this second mechanism does bridle overinvestment, as some have hoped, it requires the proper adjustment by later creditors. Consequently, its perceived efficiency effect will not materialize when security is granted to the earlier creditor. Yet the subsequent creditors, such as employees or customers, are unable to negotiate interest rates to account for existing debt obligations. Overinvestment follows and wealth is redistributed to the borrower, again, from the nonadjusting creditors. Apparently, the case for the priority of secured claims is not made any easier by this second theory of overinvestment-control when we take nonadjusting creditors into consideration.

\section{Reducing Incentives to Overinvest}

The last mechanism through which secured lending may be used to control overinvestment focuses on the debtor's incentive, rather than ability, to take up risky yet less efficient projects. It was mentioned by Professor Buckley in his study on bankruptcy priority, where he precisely noted that the debtor's incentive to overinvest can rise with the increase in the cost of credit. ${ }^{82}$ As far as security interests help lower this cost, he believes that overinvestment should be less serious a problem in the context of secured lending. ${ }^{83}$

accompanying text (noting that secured credit enhances debtors' liquidity, which can keep troubled but viable debtors out of bankruptcy). But interestingly, he believes that borrowers will reserve their assets for the issuance of secured debts to later, rather than earlier, lenders.

80. This is known as the "underinvestment problem."

81. See Schwartz, Security Interests, supra note 3, at 22 (criticizing this "staggering debt" theory of secured lending for empirical weakness).

82. Buckley, supra note 4 , at 1430 .

83. Id. at $1430,1437-38$. My research finds no allusion to this mechanism by other 
However, Professor Buckley seemingly misunderstood the exact reason why this could be a merit of secured lending. I will explain it in detail in the next part of this Article, and show that this is indeed a unique efficiency advantage of offering priority to secured creditors that sustains the presence of nonadjusting creditors. Suffice it to say here that the borrower's incentive to overinvest hinges on its entire cost of borrowing, instead of the isolated cost of secured debts. Therefore, in the world of fully informed creditors, such as that envisioned by Professor Buckley, ${ }^{84}$ secured lending will not actually depress the borrower's avidity for overinvestment.

By limiting his emphasis narrowly on the cost of secured debts alone, Professor Buckley failed to take into consideration the change in the cost of unsecured debts, which will cancel out the supposed incentive effect brought about by the creation of security interests. He also misinterpreted secured lending as a response to the preference of fully informed earlier lenders. ${ }^{85}$ When creditors are truly informed, as Professor Buckley himself indicated, the costs imposed by the debtor's adverse incentives will be borne by the debtor itself. ${ }^{86}$ So creditors should be indifferent, whether secured or not. Then, it must be the debtor's call to take advantage of the reduction in cost of credit, if any, as a consequence of issuing secured debts.

\section{E. Summary}

The literature review above indicates that the existing theories on the efficiency of secured lending are insufficient to explain the bankruptcy priority accompanying secured claims. Some of them do not entail a requirement for priority (e.g., signaling, asset substitution). Others fail to withstand the presence of nonadjusting creditors (e.g., monitoring, leverage, draining subsequent borrowing), even if they could be persuasive

law scholars, although a similar idea was introduced in the economics literature. See, e.g., Helmut Bester, The Role of Collateral in Credit Markets with Imperfect Information, 31 European ECON. Rev. 887, 895-97 (1987) (demonstrating Stiglitz and Weiss's conclusion that credit contracts can create incentive effects for entrepreneurs who are faced with a choice between various investment schemes, and that this choice antecedes a moral hazard that may result in rationing or other losses in welfare).

84. Buckley, supra note 4, at 1426 (discussing secured lending as a means of counterbalancing the shortcomings in incentives faced by companies which can otherwise be ameliorated by fully informing investors).

85. See id. at 1437-38 (arguing that principal lenders will opt into security to protect themselves against the "risk of debt alteration").

86. See id. at 1426 ("[A]dverse incentives impose costs that will be borne by the firm itself so long as investors have full information."). 
otherwise. The only promising candidate left, the incentive effect on overinvestment, seems incomplete and somewhat misleading in its current version, and may have exaggerated the potential efficiency of secured lending. I turn now to this final point.

\section{THE PARADOXES OF SECURED LENDING}

As reviewed in the previous Part, no existing theory has managed to adequately explain the priority of secured claims in bankruptcy when some creditors do not adjust interest rates to reflect the increased risk associated with their loans after issuance of secured debts. However, one effect of secured lending is missing, somewhat surprisingly, in most legal writings on the topic: To the extent that secured lending lowers the cost of capital, it can disincentivize the borrower to engage in overinvestment. ${ }^{87}$ This effect does count in favor of the priority of secured debts, for the borrower's cost of credit can be reduced only if secured lenders enjoy more favorable status in bankruptcy proceedings. ${ }^{88}$ It also sustains the presence of nonadjusting creditors, who will not alter the interest charges for their credits while secured creditors are cutting down theirs. As a result, the borrower's total burden of debt declines.

This rarely explored virtue of secured lending exhibits two paradoxes, however. For one thing, the efficiency of secured debts seems so entangled with its distributional impacts that any attempt to rein in the latter can only be done at the sacrifice of the former. For another, while secured debts remove the borrower's motivation to overinvest under certain circumstances, they also inspire the borrower to invest excessively under others.

To focus on the incentive effects resulting from the varying cost of credit, I put aside in this Part other costs involved in using secured debts. So the cost of issuing secured debts, the possibility of creditor's monitoring, as well as the borrower's ability to take precaution against tort damages, are all ignored for the moment. ${ }^{89}$

87. As noted, Professor Buckley is the one exception who noticed this efficiency effect of secured lending, though with obvious flaws. See supra notes 82-85 and accompanying text.

88. This is not to deny that the in rem nature of security and the right of foreclosure may also help bring down the interest rates charged by secured creditors. But without a priority in bankruptcy, the decrease in interest rates of secured loans is probably negligible. It is the bankruptcy priority feature that directly addresses the risk of lending, which determines the risk premium: a major component of loan interests.

89. These costs will be considered in Part V., infra. 


\section{A. The Primary Paradox: Efficiency Residing in Distribution}

Overinvesting incentives dwindle as the cost of capital drops. Yet secured lending can achieve this only if the unsecured creditors do not raise their interest rates. In other words, the overinvestment problem can be eased only if two conditions are met simultaneously: Secured creditors enjoy priority in bankruptcy and unsecured creditors are nonadjusting.

\section{Decrease in Interest Rates}

When debtors invest in risky projects that ultimately succeed, they keep the return from such investment, after paying back the principal and interests of loans. But under the limited liability regime, debtors only bear the costs of investment to the extent of the value of their assets in case of an investment failure, and any remaining cost will be shifted to their creditors. In effect, debtors are essentially gambling with other peoples' money. Rational debtors, of course, would want to keep the expected repayment obligation to their creditors as low as possible while deriving as much returns from their investments as they can. Since the debtor's return on investment is determined by the expected value of the investment project and the expected amount of debt repayment, it needs to strike a balance between the two sides when making investment decisions. As between two investment options, one with a higher probability of failure and less socially valuable than the other, the riskier one benefits the debtor by scaling down its expected repayment to the creditor because the probability of success shrinks alongside the probability of making full repayment.

At the same time however, this riskier option also has lower expected value than the relatively safer project. As the interest rate rises, the debtor's expected saving from the riskier investment project grows in view of the lower probability of making full repayment enabled by this kind of project. $^{90}$ This renders the safer option increasingly unappealing to the debtor. Therefore, the higher the interest rate charged for the loan, the more incentivized the borrower will be to invest in risky but inefficient projects, other things being equal.

90. Put differently, the borrower's expected repayment obligation grows as the committed amount of interest rises, while the riskiness of investment keeps constant. In this sense, the borrower can be viewed as internalizing a lower portion of the value of investment with the increase in interest rate. Professor Buckley presents this view in a similar way: "As the cost of credit rises, a greater portion of firm value is assigned to creditors, and the firm's temptation to gamble with other people's money increases accordingly." Buckley, supra note 4, at 1430. 
Some notations can be used to further clarify the idea. Consider a risk-neutral firm with an initial wealth of W. It is choosing between two investment projects, requiring the same amount of cost, $\mathrm{C}$, which will be financed by borrowing from a fully adjusting and risk-neutral creditor at the interest of $\mathrm{R}_{\mathrm{Ci}}$, where the subscript $\mathrm{i}$ indicates the project actually chosen by the firm. $\mathrm{R}_{\mathrm{Ci}}$ varies depending on whether the loan is secured, so it can be written as $R_{\mathrm{Ci}}(S)$, where $S=1$ if $C$ is secured, and $S=0$ if not. ${ }^{91}$

Project 1 yields a return of $\mathrm{x}_{1}$ when it succeeds with a probability of $\mathrm{p}_{1}$, while Project 2 brings in $x_{2}$ in case of success, which has a probability of $\mathrm{p}_{2}$. When they fail, neither project generates any return. Suppose Project 1 is more efficient and less risky; in other words, $\mathrm{p}_{1} \mathrm{x}_{1}>\mathrm{p}_{2} \mathrm{x}_{2}$ and $\mathrm{p}_{1}>\mathrm{p}_{2}$. Consequently, the creditor will ask for higher, or at least the same, ${ }^{92}$ rate of interest if it knows Project 2 is to be picked, all else being equal (i.e. $R_{C 1} \leq$ $\left.\mathrm{R}_{\mathrm{C} 2}\right) .^{93}$ Also assume the firm's other creditors hold total debt of $\mathrm{N}$ bearing a fixed amount of interest, $R_{N}$. The firm has enough wealth, $W$, to fully secure $\mathrm{C},{ }^{94}$ but in case of investment failure, it will not be able to repay its entire debts ${ }^{95}$ (i.e. $\mathrm{C} \leq \mathrm{W}<\mathrm{C}+\mathrm{N}$ ).

Under these setups, the firm's expected payoff from investing in Project 1 is:

$$
\mathrm{p}_{1}\left(\mathrm{x}_{1}-\mathrm{C}-\mathrm{R}_{\mathrm{C} 1}-\mathrm{N}-\mathrm{R}_{\mathrm{N}}+\mathrm{W}\right) \cdot(1)
$$

However, since even the adjusting creditor cannot know which project is eventually undertaken after the loan is advanced, the firm will be ready to pick this less risky project only if:

91. Although the firm can choose to secure any proportion of $\mathrm{C}$ in principle, it should secure the loan as fully as possible, in that the interest rate of $\mathrm{C}$ decreases with the increase in the collateral used to secure the loan and the firm's payoff rises with the decrease in interest rate, given that the firm's total debt $(\mathrm{N})$ and interest thereon $\left(\mathrm{R}_{\mathrm{N}}\right)$ are fixed.

92. When the loan is fully secured, risk of investment failure will not matter in determining the amount of interest.

93. Without loss of generality, suppose the rate of return for riskless loans is zero. Then, the interest charged for a risky loan can be written as $R=(1-p)(C-T) / p$ where $p$ is the probability of success, $\mathrm{C}$ is the amount of the loan, and $\mathrm{T}$ is the amount recoverable in case of failure. Obviously, $\mathrm{R}$ increases as $\mathrm{p}$ decreases.

94. Relaxing this assumption will not change the conclusions of this Article. Indeed, these conclusions will be valid if an adjusting creditor charges a lower interest rate when her credit is secured. For any $\mathrm{C}$ that exceeds $\mathrm{W}$, we can think of the adjusting creditor as partially secured to the extent of $\mathrm{W}$, with an unsecured credit of $\mathrm{c}=\mathrm{C}-\mathrm{W}$. It can be proved that the interest rate charged by an adjusting creditor increases in the amount of her unsecured credit. See infra note 99 and accompanying text. Since C >c, it follows that a partially secured adjusting creditor still charges a lower interest rate than a fully unsecured creditor.

95. Otherwise the loan is riskless, which renders the security unnecessary. 


$$
\mathrm{p}_{1}\left(\mathrm{x}_{1}-\mathrm{C}-\mathrm{R}_{\mathrm{Cl}}-\mathrm{N}-\mathrm{R}_{\mathrm{N}}+\mathrm{W}\right)>\mathrm{p}_{2}\left(\mathrm{x}_{2}-\mathrm{C}-\mathrm{R}_{\mathrm{Cl}}-\mathrm{N}-\mathrm{R}_{\mathrm{N}}+\mathrm{W}\right) .
$$

Otherwise, it will be better off by promising to invest in Project 1 but actually investing in the riskier Project 2. In economists' jargon, it is not incentive compatible for the firm to choose Project 1 when the interest of the loan is $\mathrm{R}_{\mathrm{C} 1}$ and:

$$
\text { (2) } \mathrm{p}_{1}\left(\mathrm{x}_{1}-\mathrm{C}-\mathrm{R}_{\mathrm{Cl}}-\mathrm{N}-\mathrm{R}_{\mathrm{N}}+\mathrm{W}\right) \leq \mathrm{p}_{2}\left(\mathrm{x}_{2}-\mathrm{C}-\mathrm{R}_{\mathrm{Cl}}-\mathrm{N}-\mathrm{R}_{\mathrm{N}}+\mathrm{W}\right) \text {. }
$$

As long as (2) is satisfied, we will see the firm invest in the inefficient Project 2. Since an adjusting creditor is informed of the parameters of these projects and understands the borrower's investment strategy, the creditor will charge $\mathrm{R}_{\mathrm{C} 2}$ as the interest of the loan, assuming that the riskier investment still makes the firm better off than the status quo. ${ }^{96}$ The firm might fare better if it could commit itself credibly to Project 1 and pay a lower interest of $\mathrm{R}_{\mathrm{C} 1}$. But since it is unable to do so, ${ }^{97}$ the only choice left is to take the loan with a higher interest and undertake the riskier project. ${ }^{98}$ This welfare loss results exactly from the agency cost of debt financing when costless monitoring is impossible. After rearrangement, the condition under which the inefficient overinvestment emerges can be written as:

$$
\text { (3) } \mathrm{p}_{1} \mathrm{x}_{1}-\mathrm{p}_{2} \mathrm{x}_{2} \leq\left(\mathrm{p}_{1}-\mathrm{p}_{2}\right)\left(\mathrm{C}+\mathrm{R}_{\mathrm{Cl}}+\mathrm{N}+\mathrm{R}_{\mathrm{N}^{-}}-\mathrm{W}\right) \text {. }
$$

The left-hand side of (3) shows the firm's cost of opting for a riskier project, the decrease in the expected value of investment projects, which is its highest possible amount of gains expected from the investment. The right-hand side of (3) is the expected benefit from the riskier project, i.e. the decrease in its expected repayment to the creditors. As the benefit exceeds the cost, the firm will go after the investment project with higher risk and lower expected value. The inequality of (3) shows that the firm's benefit from overinvesting in Project 2 expands as its promised repayment, $\mathrm{C}+\mathrm{R}_{\mathrm{Cl}}+\mathrm{N}+\mathrm{R}_{\mathrm{N}}$, increases, other things being equal.

96. To be specific, I assume W-N-R $\mathrm{R}_{\mathrm{N}}<\mathrm{p}_{2}\left[\mathrm{x}_{2}-\mathrm{C}-\mathrm{R}_{\mathrm{C} 2}(0)-\mathrm{N}-\mathrm{R}_{\mathrm{N}}+\mathrm{W}\right]$. This assumption will be relaxed in Part B. In addition, note that under the regime of limited liability, both $\mathrm{W}-\mathrm{N}-\mathrm{R}_{\mathrm{N}}$ and $\mathrm{p}_{\mathrm{i}}\left[\mathrm{x}_{\mathrm{i}}-\mathrm{C}-\mathrm{R}_{\mathrm{Ci}}-\mathrm{N}-\mathrm{R}_{\mathrm{N}}+\mathrm{W}\right]$ should be nonnegative.

97. Note that the adjusting creditor cannot control, without cost, the borrower's investment decisions made between the time of debt issuance and the time of its maturity. As monitoring is not to be considered in this section, adjusting interest rates becomes the only way to deal with the risk of lending.

98. It is not incentive-compatible for the firm to choose Project 1 when $\mathrm{R}_{\mathrm{C} 2}$ is charged and (2) is satisfied. Given (2), we have $p_{1} x_{1}-p_{2} x_{2}-\left(p_{1}-p_{2}\right)\left(C+N+R_{N}-W\right) \leq\left(p_{1}-p_{2}\right) R_{C 1}$. At the same time, since $R_{C 1} \leq R_{C 2}, p_{1} x_{1}-p_{2} x_{2}-\left(p_{1}-p_{2}\right)\left(C+N+R_{N}-W\right) \leq\left(p_{1}-p_{2}\right) R_{C 2}$, this means that $\mathrm{p}_{1}\left(\mathrm{x}_{1}-\mathrm{C}-\mathrm{R}_{\mathrm{C} 2}-\mathrm{N}-\mathrm{R}_{\mathrm{N}}+\mathrm{W}\right) \leq \mathrm{p}_{2}\left(\mathrm{x}_{2}-\mathrm{C}-\mathrm{R}_{\mathrm{C} 2}-\mathrm{N}-\mathrm{R}_{\mathrm{N}}+\mathrm{W}\right)$. 
Since $\mathrm{p}_{1}>\mathrm{p}_{2}$, we can divide both sides of (3) by $\mathrm{p}_{1}-\mathrm{p}_{2}$, and get:

(4) $\left(\mathrm{p}_{1} \mathrm{x}_{1}-\mathrm{p}_{2} \mathrm{x}_{2}\right) /\left(\mathrm{p}_{1}-\mathrm{p}_{2}\right) \leq \mathrm{C}+\mathrm{R}_{\mathrm{Cl}}+\mathrm{N}+\mathrm{R}_{\mathrm{N}}-\mathrm{W}$.

Let us define the left-hand side of the inequality (4) as D. The value of $\mathrm{D}$ varies with the specific characteristics of the potential projects denoted by p's and x's. Regardless of the exact values of p's and x's, the condition for the firm to prefer the riskier project represented by (4) will be easier to satisfy as the value of the right-hand side increases. Since C, N, $\mathrm{R}_{\mathrm{N}}$, and $\mathrm{W}$ are all fixed by assumptions, the firm's incentive to overinvest strengthens as $R_{C 1}$, the amount of interest charged by the lender to finance the less risky project, increases..$^{99}$

As already noted, secured lending contributes to reducing loan interests, in that the priority granted to secured lenders in bankruptcy attenuates the risk of their loans. Adding a few more assumptions to the previous model can readily prove this. Assume that the riskless rate of return is zero. Then a fully secured lender enjoying unimpaired priority will charge zero interest. But if it is unsecured and subject to a pro rata distribution in bankruptcy, the lender will charge a positive rate of interest. Using the notations, we can write $\mathrm{R}_{\mathrm{Cl}}(1)=0$, and $\mathrm{R}_{\mathrm{Cl}}(0)=\mathrm{C}\left(1-\mathrm{p}_{1}\right)[1$ $\mathrm{W} /(\mathrm{C}+\mathrm{N})] / \mathrm{p}_{1} \cdot{ }^{100}$ Therefore, secured lending induces the firm to invest in Project 2 if:

$$
\mathrm{D} \leq \mathrm{C}+\mathrm{N}+\mathrm{R}_{\mathrm{N}}-\mathrm{W},(5)
$$

whereas unsecured lending drives it to choose this riskier project if:

$$
\mathrm{D} \leq \mathrm{C}+\mathrm{C}\left(1-\mathrm{p}_{1}\right)[1-\mathrm{W} /(\mathrm{C}+\mathrm{N})] / \mathrm{p}_{1}+\mathrm{N}+\mathrm{R}_{\mathrm{N}}-\mathrm{W} \cdot(6) .
$$

Compared with secured lending, unsecured lending tends to inflate the

99. Suppose p's and x's are all random variables. Then D itself is a random variable. If we write out its cumulative distribution function as $\mathrm{F}(\mathrm{d})$, then the probability for the firm to opt for the riskier and inefficient Project 2 is $\mathrm{F}\left(\mathrm{C}+\mathrm{R}_{\mathrm{C}}+\mathrm{N}+\mathrm{R}_{\mathrm{N}}-\mathrm{W}\right)$, which rises with the value of the right-hand side of (4). Fundamentally, this is a simplified demonstration of a more general proposition. As first suggested by Jensen and Meckling's seminal paper on the agency costs of debt financing, as the promised debt payment increases, the debtor increases monotonically the risk of its investment strategy. See Jensen \& Meckling, supra note 32 (demonstrating that the agency cost of debt increases as the amount of outside financing increases); see also Green \& Talmor, supra note 32 (providing a more general proof of this proposition).

100. Solve $\mathrm{p}_{1}\left[\mathrm{C}+\mathrm{R}_{\mathrm{Cl}}(0)\right]+\left(1-\mathrm{p}_{1}\right)\left[\mathrm{W}^{*} \mathrm{C} /(\mathrm{C}+\mathrm{N})\right]=\mathrm{C}$. For simplicity, $\mathrm{I}$ assume that the interest of either credit, $\mathrm{C}$ or $\mathrm{N}$, has not accrued when the investment fails and the firm files bankruptcy. Thus, neither is included in calculating the bankruptcy claims. See 11 U.S.C. § 502(b)(2) (2012) (listing the exceptions to the allowance of bankruptcy claims or interests). 
likelihood that the inefficient Project 2 is selected, since $C\left(1-p_{1}\right)[1-$ $\mathrm{W} /(\mathrm{C}+\mathrm{N})] / \mathrm{p}_{1}$ will be nonnegative given $\mathrm{p}_{1}<1$ and $\mathrm{W}<\mathrm{C}+\mathrm{N}$.

\section{Presence of Nonadjusting Creditors}

As inequalities (3) and (4) show, the debtor's benefit from carrying out the riskier project depends on the entire amount of repayment to all creditors, both secured and unsecured. The debtor's incentive to overinvest cannot be reduced if the unsecured creditors raise their interest rates to compensate for the heightened risk owing to the issuance of secured debts. When unsecured creditors are fully adjusting, the debtor's savings in interest payments on secured loans will be cancelled out by the additional charges made to account for the extra risk of unsecured credits. As a result, the total cost of credit remains unchanged. In brief, the efficiency of secured lending in discouraging overinvestment will occur only if at least some unsecured creditors do not peg their interest rates to the debtor's use of secured debts. ${ }^{101}$

The analysis thus far has shown the following two interlinked points. First, secured lending, with its priority in bankruptcy, can promote efficiency by moderating the borrower's incentive to overinvest. Second, this efficiency effect relies precisely on the existence of nonadjusting creditors. In other words, the efficiency of secured lending goes hand-inhand with its distributional effects. Fundamentally, these two countering facets of the welfare impact lead to the primary paradox of secured lending.

The intuition behind this paradox is easy to understand. Indeed, it is foreshadowed by "the puzzle of secured debt." Secured lending should generate no social benefit insofar as risk-neutral creditors have

101. This can be observed if the previous model is extended by allowing the interest of $\mathrm{N}, \mathrm{R}_{\mathrm{Ni}}$, to change based on whether the finance for investment is obtained as a secured loan. If the loan is fully secured, as stated above, $\mathrm{R}_{\mathrm{Ci}}(1)$ is zero, and $\mathrm{R}_{\mathrm{Ni}}(1)$ can be solved from $\mathrm{p}_{\mathrm{i}}\left(\mathrm{N}+\mathrm{R}_{\mathrm{Ni}}\right)+\left(1-\mathrm{p}_{\mathrm{i}}\right)(\mathrm{W}-\mathrm{C})=\mathrm{N}$, which is $\left(1-\mathrm{p}_{\mathrm{i}}\right)(\mathrm{C}+\mathrm{N}-\mathrm{W}) / \mathrm{p}_{\mathrm{i}}$. So the necessary condition for the firm to opt for Project 2, when secured lending is used, is $\mathrm{D} \leq \mathrm{C}+\mathrm{N}+\mathrm{R}_{\mathrm{C} 1}(1)+\mathrm{R}_{\mathrm{N} 1}(1)-\mathrm{W}$ $=\mathrm{C}+\mathrm{N}+0+\left(1-\mathrm{p}_{1}\right)(\mathrm{C}+\mathrm{N}-\mathrm{W}) / \mathrm{p}_{1}-\mathrm{W}$.

On the other hand, if an unsecured loan is used to finance the investment project, both creditors will be subject to pro-rata distributions once the borrower goes bankrupt. Hence, $\mathrm{R}_{\mathrm{Ci}}(0)$ is the solution to $\mathrm{p}_{\mathrm{i}}\left(\mathrm{C}+\mathrm{R}_{\mathrm{Ci}}\right)+\left(1-\mathrm{p}_{\mathrm{i}}\right)[\mathrm{W} * \mathrm{C} /(\mathrm{C}+\mathrm{N})]=\mathrm{C}$, and similarly, $\mathrm{R}_{\mathrm{Ni}}(0)$ can be calculated by solving $\mathrm{p}_{\mathrm{i}}\left(\mathrm{N}+\mathrm{R}_{\mathrm{Ni}}\right)+\left(1-\mathrm{p}_{\mathrm{i}}\right)[\mathrm{W} * \mathrm{~N} /(\mathrm{C}+\mathrm{N})]=\mathrm{N}$, which is $\mathrm{N}\left(1-\mathrm{p}_{\mathrm{i}}\right)[1-$ $\mathrm{W} /(\mathrm{C}+\mathrm{N})] / \mathrm{p}_{\mathrm{i}}$.

Accordingly, in the case of unsecured lending, the necessary condition for the firm to choose the riskier project becomes $\mathrm{D} \leq \mathrm{C}+\mathrm{N}+\mathrm{R}_{\mathrm{Cl}}(0)+\mathrm{R}_{\mathrm{N} 1}(0)-\mathrm{W}$, and the right-hand side of this inequality turns out to be $\mathrm{C}+\mathrm{N}+\left(1-\mathrm{p}_{1}\right)(\mathrm{C}+\mathrm{N}-\mathrm{W}) / \mathrm{p}_{1}-\mathrm{W}$, too. In short, as far as all creditors are adjusting, the total cost of credit converges no matter whether the loan used to finance the investment is secured or not, and therefore the firm will choose the same investment project. 
homogenous expectations about default probability, can assess the risks of default reasonably accurately, and can adjust interest rates based on this assessment. $^{102}$ Hence, any efficiency in secured lending must be a consequence of a deviation from the prototypical creditor. Without lingering over the empirically controversial features of this prototype, riskneutrality, and homogenous expectations, then creditors' weaknesses in evaluating default risk and accounting for it in interest rates inevitably emerges as a possible source of inefficiency that can be remedied by secured lending.

Surprisingly, most legal scholars have never mentioned the advantage of security interests in restraining the borrower's incentive, rather than ability, to invest in an excessively risky way. For those who have mentioned it, the paradoxical nature of this incentive's effect was plainly neglected. ${ }^{103}$ This oversight might have resulted in an exaggeration of the efficiency of secured lending. The primary paradox shows that - to borrow two terms from Professor Buckley - the "soft defenses of secured lending" have difficulty coexisting with the "hard defenses of secured lending,"104 at least in terms of control over the borrower's adverse incentives. ${ }^{105}$ As Buckley notes, "soft defenses" offer no affirmative justification for secured lending; instead, they prove only that the practice lacks distributional effects. ${ }^{106}$ "Hard defenses," in contrast, positively assert that secured lending promotes efficiency goals. ${ }^{107}$ Soft defenses, then, inevitably undermine the merit of secured lending as they constrain overinvestment, focusing instead on the lack of distributional effects. The insignificant loss suffered by nonadjusting creditors necessarily implies a minor incentive efficiency that stems from the issuance of secured debts.

Moreover, it is a particularly forceful strike against his hard defenses when Professor Buckley suggested superpriority rights as a remedy for distributional disadvantage suffered by tort creditors. ${ }^{108}$ Allowing these truly nonadjusting creditors to prevail over all other creditors in bankruptcy

102. See Schwartz, Security Interests, supra note 3.

103. Professor Buckley neglected this issue in his discussion about the influence of security interests on borrowers' adverse incentives. Buckley, supra note 4, at 1426-39. It seems that financial economists largely ignore the importance of non-adjusting creditors in discouraging overinvestment as well. See, e.g., Bester, supra note 83.

104. Buckley, supra note 4 , at 1402-04. Soft defenses aim at qualifying the distributional impacts of secured lending, while the hard defenses aim at illuminating its efficiency benefits. See id., supra note 4, at 1404-39 (comparing between soft defenses and hard defenses).

105. The primary paradox may also exist in the context of screening efficiency, which is another one of Professor Buckley's hard defenses of secured lending. See Part VI.B. infra.

106. Buckley, supra note 4, at 1404.

107. Id. at 1403-04

108. Id. at 1406 . 
would raise secured lenders' interest charges, without any corresponding decrease in the amount of bankruptcy claims held by the tort claimants. The borrower's total cost of credit, therefore, is bound to grow, which, as Professor Buckley himself admitted, will spark even more overinvestment. ${ }^{109}$ Although the proposal is made to strengthen his soft defenses, it effectively defeats his own commendation for secured lending as a constraint on overinvestment when super-secured tort creditors dwarf secured lenders. This contradiction in viewpoints is attributable once again to the lack of awareness of this Article's proposed primary paradox associated with secured lending.

\section{B. Secondary Paradox: Exacerbating and Alleviating Overinvestment}

Ironically, secured lending not only alleviates the overinvestment problem, but, at times, can also exacerbate it. This ostensible contradiction rests on the fact that the lower cost of credit allows the borrower both to better internalize the value of investment and to have easier access to credit. This latter effect feeds the borrower's appetite for inefficient investments that could not be financed without the option of secured lending. ${ }^{110}$ The legal literature treats these conflicting effects of secured lending separately. While some writers blame it for encouraging inefficient investments, a few others praise it for curbing borrowers' adverse incentives. ${ }^{111}$ Amazingly, however, no effort has been made to link them coherently and present a less partial view of secured financing.

Let's continue with the model set up in A.1 of Part IV. Up to this point, I have assumed that the firm, when it borrows on an unsecured basis, can still reap a positive net gain even if it chooses the riskier, yet less efficient, investment project and pays a higher interest, or:

$$
\mathrm{W}-\mathrm{N}-\mathrm{R}_{\mathrm{N}}<\mathrm{p}_{2}\left[\mathrm{x}_{2}-\mathrm{C}-\mathrm{R}_{\mathrm{C} 2}(0)-\mathrm{N}-\mathrm{R}_{\mathrm{N}}+\mathrm{W}\right]{ }^{112}
$$

So, be it secured or not, the firm will borrow from the adjusting creditor in any event. But once we relax this assumption, it becomes clear that sometimes the firm will not borrow at all if a secured loan is not available, because the interest rate will be too high to justify any investment. When it is socially inefficient to invest in certain potential projects, i.e. projects

109. Id. at 1430 .

110. See, e.g., Triantis, Free-Cash-Flow, supra note 77, at 2163 (explaining secured debt and creditor priorities).

111. Buckley, supra note 4, at 1430.

112. See supra note 96 (noting that the assumption $\mathrm{W}-\mathrm{N}-\mathrm{R}_{\mathrm{N}}<\mathrm{p}_{2}\left[\mathrm{x}_{2}-\mathrm{C}-\mathrm{R}_{\mathrm{C} 2}(0)-\mathrm{N}-\mathrm{R}_{\mathrm{N}}+\mathrm{W}\right]$ would be relaxed in this section). 
with expected values lower than their costs, secured lending nonetheless facilitates the financing of such undesirable investments.

We can write out the complete conditions for the firm to undertake the two projects illustrated in A.1. It picks Project 1 only if:

(7) $\mathrm{p}_{1}\left(\mathrm{x}_{1}-\mathrm{C}-\mathrm{R}_{\mathrm{C} 1}-\mathrm{N}-\mathrm{R}_{\mathrm{N}}+\mathrm{W}\right)>\mathrm{p}_{2}\left(\mathrm{x}_{2}-\mathrm{C}-\mathrm{R}_{\mathrm{Cl}}-\mathrm{N}-\mathrm{R}_{\mathrm{N}}+\mathrm{W}\right)$, and

(8) W-N-R $\mathrm{R}_{\mathrm{N}}<\mathrm{p}_{1}\left(\mathrm{x}_{1}-\mathrm{C}-\mathrm{R}_{\mathrm{Cl}}-\mathrm{N}-\mathrm{R}_{\mathrm{N}}+\mathrm{W}\right)$.

The firm chooses Project 2 when:

(2) $\mathrm{p}_{1}\left(\mathrm{x}_{1}-\mathrm{C}-\mathrm{R}_{\mathrm{Cl}}-\mathrm{N}-\mathrm{R}_{\mathrm{N}}+\mathrm{W}\right) \leq \mathrm{p}_{2}\left(\mathrm{x}_{2}-\mathrm{C}-\mathrm{R}_{\mathrm{Cl}}-\mathrm{N}-\mathrm{R}_{\mathrm{N}}+\mathrm{W}\right)$, and

(9)W-N-R $\mathrm{R}_{\mathrm{N}}<\mathrm{p}_{2}\left(\mathrm{x}_{2}-\mathrm{C}-\mathrm{R}_{\mathrm{C} 2}-\mathrm{N}-\mathrm{R}_{\mathrm{N}}+\mathrm{W}\right)$.

Finally, the firm will choose not to borrow at all if:

(7) $\mathrm{p}_{1}\left(\mathrm{x}_{1}-\mathrm{C}-\mathrm{R}_{\mathrm{Cl}}-\mathrm{N}-\mathrm{R}_{\mathrm{N}}+\mathrm{W}\right)>\mathrm{p}_{2}\left(\mathrm{x}_{2}-\mathrm{C}-\mathrm{R}_{\mathrm{Cl}}-\mathrm{N}-\mathrm{R}_{\mathrm{N}}+\mathrm{W}\right)$, and (10) W-N-R $\mathrm{R}_{\mathrm{N}} \geq \mathrm{p}_{1}\left(\mathrm{x}_{1}-\mathrm{C}-\mathrm{R}_{\mathrm{Cl}}-\mathrm{N}-\mathrm{R}_{\mathrm{N}}+\mathrm{W}\right)^{113}$;

or if:

(2) $\mathrm{p}_{1}\left(\mathrm{x}_{1}-\mathrm{C}-\mathrm{R}_{\mathrm{Cl}}-\mathrm{N}-\mathrm{R}_{\mathrm{N}}+\mathrm{W}\right) \leq \mathrm{p}_{2}\left(\mathrm{x}_{2}-\mathrm{C}-\mathrm{R}_{\mathrm{C} 1}-\mathrm{N}-\mathrm{R}_{\mathrm{N}}+\mathrm{W}\right)$, and

(11) W-N-R $\mathrm{R}_{\mathrm{N}} \geq \mathrm{p}_{2}\left(\mathrm{x}_{2}-\mathrm{C}-\mathrm{R}_{\mathrm{C} 2}-\mathrm{N}-\mathrm{R}_{\mathrm{N}}+\mathrm{W}\right)$;

or if:

(10)W-N-R $\mathrm{R}_{\mathrm{N}} \geq \mathrm{p}_{1}\left(\mathrm{x}_{1}-\mathrm{C}-\mathrm{R}_{\mathrm{Cl}}-\mathrm{N}-\mathrm{R}_{\mathrm{N}}+\mathrm{W}\right)$, and

(11)W-N-R $\mathrm{R}_{\mathrm{N}} \geq \mathrm{p}_{2}\left(\mathrm{x}_{2}-\mathrm{C}-\mathrm{R}_{\mathrm{C} 2}-\mathrm{N}-\mathrm{R}_{\mathrm{N}}+\mathrm{W}\right)$.

In A.1 of this Part, I demonstrated that secured lending disincentivizes overinvestment when the firm can gain from investing in risky projects even if it has to pay the higher amount of interest, $\mathrm{R}_{\mathrm{C} 2}(0)$. Now I will explore the opposite case. When it does not pay to invest in Project 2 with an unsecured loan, i.e. $\mathrm{W}-\mathrm{N}-\mathrm{R}_{\mathrm{N}} \geq \mathrm{p}_{2}\left[\mathrm{x}_{2}-\mathrm{C}-\mathrm{R}_{\mathrm{C} 2}(0)-\mathrm{N}-\mathrm{R}_{\mathrm{N}}+\mathrm{W}\right]$, three scenarios need to be considered: (a) it does not pay to invest either in Project 1 with an unsecured loan or $\mathrm{W}-\mathrm{N}-\mathrm{R}_{\mathrm{N}} \geq \mathrm{p}_{1}\left[\mathrm{x}_{1}-\mathrm{C}-\mathrm{R}_{\mathrm{Cl}}(0)-\mathrm{N}-\mathrm{R}_{\mathrm{N}}+\mathrm{W}\right]$; Ib) it pays to invest in Project 1 with an unsecured loan, but the firm cannot credibly commit to undertaking this investment if the interest is set at $\mathrm{R}_{\mathrm{Cl}}(0)$; i.e., when W-N-R $\mathrm{R}_{\mathrm{N}}<\mathrm{p}_{1}\left[\mathrm{x}_{1}-\mathrm{C}-\mathrm{R}_{\mathrm{Cl}}(0)-\mathrm{N}-\mathrm{R}_{\mathrm{N}}+\mathrm{W}\right]$ and $\mathrm{p}_{1}\left[\mathrm{x}_{1}-\mathrm{C}-\mathrm{R}_{\mathrm{Cl}}(0)-\mathrm{N}-\mathrm{R}_{\mathrm{N}}+\mathrm{W}\right] \leq$ $\mathrm{p}_{2}\left[\mathrm{x}_{2}-\mathrm{C}-\mathrm{R}_{\mathrm{Cl}}(0)-\mathrm{N}-\mathrm{R}_{\mathrm{N}}+\mathrm{W}\right]$; and (c) it pays to invest in Project 1 with an

113. When the inequalities (7) and (10) are satisfied, it must be true that $\mathrm{p}_{2}\left(\mathrm{x}_{2}-\mathrm{C}-\mathrm{R}_{\mathrm{C} 2}-\mathrm{N}\right.$ $\left.\mathrm{R}_{\mathrm{N}}+\mathrm{W}\right)<\mathrm{W}-\mathrm{N}-\mathrm{R}_{\mathrm{N}}$ (Given (7), $\mathrm{p}_{1} \mathrm{x}_{1}-\mathrm{p}_{2} \mathrm{x}_{2}-\left(\mathrm{p}_{1}-\mathrm{p}_{2}\right)\left(\mathrm{C}+\mathrm{N}+\mathrm{R}_{\mathrm{N}}-\mathrm{W}\right)-\left(\mathrm{p}_{1}-\mathrm{p}_{2}\right) \mathrm{R}_{\mathrm{C} 1}>0$; since $\left(\mathrm{p}_{1}-\right.$ $\left.\mathrm{p}_{2}\right) \mathrm{R}_{\mathrm{C} 1}-\left(\mathrm{p}_{1} \mathrm{R}_{\mathrm{C} 1}-\mathrm{p}_{2} \mathrm{R}_{\mathrm{C} 2}\right)=\mathrm{p}_{2}\left(\mathrm{R}_{\mathrm{C} 2}-\mathrm{R}_{\mathrm{C} 1}\right) \geq 0, \mathrm{p}_{1} \mathrm{x}_{1}-\mathrm{p}_{2} \mathrm{x}_{2}-\left(\mathrm{p}_{1}-\mathrm{p}_{2}\right)\left(\mathrm{C}+\mathrm{N}+\mathrm{R}_{\mathrm{N}}-\mathrm{W}\right)-\left(\mathrm{p}_{1} \mathrm{R}_{\mathrm{C} 1}-\mathrm{p}_{2} \mathrm{R}_{\mathrm{C} 2}\right)>$ 0 , i.e. $\left.\mathrm{p}_{2}\left(\mathrm{x}_{2}-\mathrm{C}-\mathrm{R}_{\mathrm{C} 2}-\mathrm{N}-\mathrm{R}_{\mathrm{N}}+\mathrm{W}\right)<\mathrm{p}_{1}\left(\mathrm{x}_{1}-\mathrm{C}-\mathrm{R}_{\mathrm{Cl}}-\mathrm{N}-\mathrm{R}_{\mathrm{N}}+\mathrm{W}\right)\right)$. Therefore, the firm is not willing to invest in Project 2, either. 
unsecured loan, and the firm can credibly commit itself to this investment if the interest is set at $\mathrm{R}_{\mathrm{Cl}}(0)$; i.e., $\mathrm{W}-\mathrm{N}-\mathrm{R}_{\mathrm{N}}<\mathrm{p}_{1}\left[\mathrm{x}_{1}-\mathrm{C}-\mathrm{R}_{\mathrm{Cl}}(0)-\mathrm{N}-\mathrm{R}_{\mathrm{N}}+\mathrm{W}\right]$ and $\mathrm{p}_{1}\left[\mathrm{x}_{1}-\mathrm{C}-\mathrm{R}_{\mathrm{Cl}}(0)-\mathrm{N}-\mathrm{R}_{\mathrm{N}}+\mathrm{W}\right]>\mathrm{p}_{2}\left[\mathrm{x}_{2}-\mathrm{C}-\mathrm{R}_{\mathrm{Cl}}(0)-\mathrm{N}-\mathrm{R}_{\mathrm{N}}+\mathrm{W}\right]$. The firm will not want to borrow and invest in scenarios a) and b) if secured borrowing is impossible ${ }^{114}$; in scenario (c), it will invest in Project $1 .{ }^{115}$

In the event that neither project is socially efficient; i.e., $\mathrm{p}_{2} \mathrm{x}_{2}<\mathrm{p}_{1} \mathrm{x}_{1}<$ $\mathrm{C}$, investment in either of them is undesirable. In scenario (a), secured lending lowers the interest charged by the adjusting creditor, so it raises the probabilities that (7), (8), and (9) will be satisfied, which means the firm becomes more likely to undertake one of these investments. Similarly, in scenario (b), secured lending makes (7) and (9) easier to satisfy, so that the firm will also become more enthusiastic about investing in one of those two projects. In scenario (c), secured lending increases the likelihood of (9) being satisfied, but this will not influence the firm's investment decision. As a whole, therefore, secured lending tends to encourage overinvestment when the firm is presented with only inefficient investment opportunities, and is not willing to borrow unsecured loans to finance the riskier project.

We see that secured lending can exacerbate the overinvestment problem in another case after we abandon the assumption W-N- $\mathrm{R}_{\mathrm{N}}<\mathrm{p}_{2}\left[\mathrm{x}_{2^{-}}\right.$ $\left.\mathrm{C}-\mathrm{R}_{\mathrm{C} 2}(0)-\mathrm{N}-\mathrm{R}_{\mathrm{N}}+\mathrm{W}\right]$. When only the less risky Project 1 is socially efficient; i.e., $\mathrm{p}_{1} \mathrm{x}_{1}>\mathrm{C}>\mathrm{p}_{2} \mathrm{x}_{2}$, we hope to undertake Project 1 , not Project 2 . Yet secured lending seems to be an awkward tool to achieve this goal. In both scenarios (a) and (b), secured lending, by reducing the amount of interests, enhances the probability of inequality (9) being satisfied. Nevertheless, the reduction in interests may not be so significant as to meet the condition (7). Consequently, sometimes we will have a case where inequalities (2) and (9) are satisfied after a secured debt is used; hence the inefficient Project 2, rather than Project 1, is undertaken. ${ }^{116}$ In general, as shown by the inequality (4), secured lending tends to distort investment incentives by encouraging overinvestment. This is true when the borrower encounters an investment opportunity set in which the ratio of the difference in expected values to the difference in success probabilities is too low to attract the borrower to the efficient project, and the lower interest charged by a secured lender makes the inefficient project appealing

114. Inequalities (10) and (11) are satisfied in scenario (a), and inequalities (2) and (11) are satisfied in scenario (b).

115. Inequalities (7) and (8) are satisfied in scenario (c).

116. In both scenarios (a) and (b), the decrease in interest may also cause the concurrent satisfaction of inequalities (7) and (8) so that the desirable outcome emerges. These are the cases where secured lending helps overcome the underinvestment problem, which will be discussed later in this Article. Moreover, secured lending might render conditions (2) and (8) satisfied in scenario (a), and condition (9) met in situation (c); however, neither will lead to different investment decisions. 
to the same borrower.

To complete our analysis, let's look at the case in which both investment projects generate net gains to the society:

$$
\left(\mathrm{C}<\mathrm{p}_{2} \mathrm{x}_{2}<\mathrm{p}_{1} \mathrm{x}_{1}\right) \text {, yet } \mathrm{W}-\mathrm{N}-\mathrm{R}_{\mathrm{N}} \geq \mathrm{p}_{2}\left[\mathrm{x}_{2}-\mathrm{C}-\mathrm{R}_{\mathrm{C} 2}-\mathrm{N}-\mathrm{R}_{\mathrm{N}}+\mathrm{W}\right] .
$$

Clearly, allowing for secured lending here will not give rise to any concern for overinvestment. If the more efficient project 1 is picked even when the loan is unsecured, using secured debts should not alter the borrower's decision. If neither project will be undertaken without a secured loan, then the lower interest charged by a secured lender raises the probability that one of these efficient projects will be undertaken. ${ }^{117}$

The numeric illustrations below demonstrate the two aforementioned circumstances in which secured lending may exacerbate the overinvestment problem.

Example 1. Firm is a risk-neutral debtor. The value of Firm's own assets, which can be used as collateral, is $\$ 1,000$, and this value does not change with the outcome of prospective investments. Suppose the interest rate for a risk-free loan is zero. At $\mathrm{t}_{0}$, Firm issues a debt of $\$ 1,000$, secured or unsecured, to a risk-neural adjusting Creditor 2 in order to finance the investment in one of the following two projects. Project 1 has an upside of $\$ 1,800$, and its probability of success is $50 \%$. The upside of Project 2 is $\$ 8,400$, and its probability of success is $10 \%$. If failed, both projects yield nothing. Firm makes a choice between these two projects at $t_{1}$, after the debt is issued. The outcomes of these projects become clear at $t_{2}$.

In addition, another Firm's creditor, Creditor 1, has an outstanding unsecured credit of $\$ 500$ and is completely ignorant of the riskiness of its credit, so it charges zero interest regardless of Firm's investment and financing strategies. Firm's obligations to both creditors mature at $\mathrm{t}_{2}$, and it will go bankrupt if the total amount of debt obligations exceeds its asset value. ${ }^{118}$ Finally, to focus on the overinvestment incentive caused by secured lending, assume awarding security interests is costless.

Obviously, neither Project 1 nor Project 2 is worth pursing from the social perspective. Nevertheless, Firm will choose to invest in Project 2 if it can obtain a secured loan from Creditor 2. When secured, Creditor 2 will ask for zero interest since its loan is riskless under this circumstance. Then,

117. In this case, secured lending can enhance social welfare by alleviating the underinvestment problem. See Part VI.A. infra (clarifying the usage of the term "underinvestment" as herein stated).

118. To simplify calculation, I assume again that the loan interest should not be included in Creditor 2's bankruptcy claim. 
Firm's net gain from Project 1 will be 50\%(1,800-1,000-500+1,000) $(1,000-500)=\$ 150$, but its gain will be even greater if it invests in Project 2 , which amounts to $10 \%(8,400-1,000-500+1,000)-(1,000-500)=\$ 290$.

When unsecured, on the contrary, Creditor 2 will expect to receive a pro rata distribution in the event of Firm's bankruptcy. This forces it to adjust the interest rates to reflect the riskiness of the loan. If Firm invests in Project 1, Creditor 2 should charge an interest of $\$ 333$, the solution to the equation $50 \%(1,000+r)+50 \% * 1,000 * 1,000 /(500+1,000)=1,000$ where $r$ stands for the amount of interest. However, if the interest is indeed set at $\$ 333$, Firm will be better off by investing in Project 2 since $10 \%(8,400-1,000-500-333+1,000)-(1,000-500)=\$ 256.7$, greater than $50 \%(1,800-1,000-500-333+1,000)-(1,000-500)=-\$ 16.5$. Knowing this, Creditor 2 will be willing to lend unsecured only if the amount of interest is $\$ 3,000$, the solution to $10 \%(1,000+r)+90 \% * 1,000 * 1,000 /(500+1,000)=$ 1,000 . But then Firm will not want to invest at all, because neither project will generate a positive gain compared to the status quo. ${ }^{119}$ Therefore, the inefficient investment can be avoided if secured lending is not permitted.

Example 2. Suppose the upside of Project 1 rises to $\$ 2,050$ and all other settings are the same as the previous example. Now Project 1 is socially efficient since its expected value is greater than its cost. But secured lending will still prompt Firm to invest in the inefficient Project 2 since, given the probabilities of success, the expected value of Project 1 is not high enough to appeal to the borrower. ${ }^{120}$ When a secured debt is used and Creditor 2 charges zero interest, Firm's net gain from the two projects can be calculated, respectively, as $50 \%(2,050-1,000-500+1,000)-(1,000-$ $500)=\$ 275$ and $10 \%(8,400-1,000-500+1,000)-(1,000-500)=\$ 290$. From Firm's point of view, Project 2 is preferable to Project 1, notwithstanding the fact that the society will suffer a net loss of $\$ 160$ from the former.

As in Example 1, Firm will refrain from investing if secured lending is not an option. An unsecured Creditor 2 will again ask for an interest of $\$ 3,000,{ }^{121}$ leaving Firm a net loss with either investment project. Consequently, in this case, secured lending triggers an incentive to overinvest as well. ${ }^{122}$

119. Firm's net gain from Project 2 will be $10 \%(8,400-1,000-500-3,000+1,000)-500$ $=-\$ 10$, and its net gain from Project 1 even lower.

120. In this example, Project 1 will be more attractive than its alternative if its expected value is greater than $\$ 1,040$ or its upside is greater than $\$ 2,080$.

121. Note that the probability of failure is the same as in Example 1, so the amount of interest will not change, either. Again, setting the interest at $\$ 333$, Creditor 2 will see Firm opt for Project 2.

122. It is worth noting, though, that disallowing the use of secured debts triggers an 
So far, I have depicted the secondary paradox of secured lending: It will both discourage and encourage overinvestment when the law allows the borrower to grant security interests at will. This paradox is secondary in the sense that it is a consequence of the fact that the distributional effect is a necessary condition for the adverse-incentive-undermining efficiency of secured lending, the thrust of the primary paradox. In terms of its effect on overinvestment, the two opposite momentums of secured lending both arise from its distributional impact. We have seen that $\mathrm{W}-\mathrm{N}-\mathrm{R}_{\mathrm{N}} \geq \mathrm{p}_{2}\left[\mathrm{x}_{2}-\mathrm{C}-\right.$ $\mathrm{R}_{\mathrm{C} 2}(0)-\mathrm{N}-\mathrm{R}_{\mathrm{N}}+\mathrm{W}$ ] is a necessary condition for secured debts to encourage overinvestment, and that this condition is more likely to be met as $\mathrm{p}_{2} \mathrm{x}_{2}$ decreases. ${ }^{123}$ Therefore, all other things being equal, secured lending will be increasingly undesirable, in terms of its effect on the borrower's overinvesting incentive, as the expected value of the riskier investment project decreases.

This secondary paradox implies that mechanisms to insulate nonadjusting creditors from distributional effects might constrain overinvestment in some situations, especially when the borrower only has investment opportunities with relatively low returns. Yet in other situations, these mechanisms can strengthen overinvesting incentives since the borrower's overall cost of capital rises as nonadjusting creditors are protected from cost externalization. Bebchuk and Fried's proposal of "partial priority" is one of the distribution-preventing mechanisms. ${ }^{124}$ With the demotion of secured creditors in the rank of bankruptcy distribution, the vice of security is dispelled, but so is its virtue. Another frequently suggested mechanism would confer superpriority on tort creditors. ${ }^{125}$ By the same token, however, it is expected to alleviate overinvestment in some circumstances while exacerbate the problem in others. ${ }^{126}$ There also seems

unexplored opportunity of investment in a positive NPV project; i.e., the problem of underinvestment, which will be discussed later.

123. As $\mathrm{x}_{2}-\mathrm{C}-\mathrm{R}_{\mathrm{C} 2}(0)-\mathrm{N}-\mathrm{R}_{\mathrm{N}}+\mathrm{W} \geq 0$ due to limited liability, $\mathrm{p}_{2}\left[\mathrm{x}_{2}-\mathrm{C}-\mathrm{R}_{\mathrm{C} 2}(0)-\mathrm{N}-\mathrm{R}_{\mathrm{N}}+\mathrm{W}\right)$ drops with both $\mathrm{p}_{2}$ and $\mathrm{x}_{2}$.

124. See Bebchuk \& Fried, Uneasy Case 1, supra note 5, at 904-13 (describing two types of partial priority systems: an "adjustable priority rule" and "fixed-fraction priority rule"); see also Bebchuk \& Fried, Uneasy Case 2, supra note 5, at 1323-37 (discussing the effects of implementing partial priority).

125. See the literature cited in supra note 7 for details of this suggestion.

126. To illustrate, consider the following variant of Example 1. Let the upsides of Project 1 and Project 2 increase respectively to $\$ 3,000$ and $\$ 12,000$, all other conditions being the same. When Creditor 1 is entitled to superpriority, Firm will not bother to create a security interest for Creditor 2, so the latter will charge an interest of $\$ 4,500$ (note that a $\$ 500$ interest cannot induce Firm to stick to Project 1). At this interest rate, Firm is incentivized to pick the less-efficient Project 2. On the contrary, if Creditor 1 is not protected by superpriority, Firm can grant Creditor 2 a security interest, in which case 
to be a widespread belief that awarding priority to prior creditors restricts overinvestment by the borrower. ${ }^{127}$ Nevertheless, if the prior creditor is nonadjusting, the first-in-time priority will carry the same paradoxical effects on overinvestment. Therefore, perhaps it is premature to recommend the "internalizing" legal mechanisms before we have a clearer idea about the magnitudes of their contradictory impacts.

\section{MAJOR COSTS OF THE PARADOXICAL SECURED LENDING REVISITED}

The paradoxes presented above remind us of the uncomfortable fact that secured lending is a double-edged sword: It may benefit our society as a whole, but only at the expense of some of its members; it improves our well-being at some points in time, but causes damages at others. This is true even if the secured creditors, with priority in bankruptcy, influence only the borrowers' investment strategies. However, their impact is certainly beyond that. Section C. of Part II summarized the consequences when secured lending distributes welfare among the relevant parties. In this section, I will illustrate two of these consequences: reduced monitoring efforts and distorted precaution incentives. For the latter, I will utilize numerical examples to illustrate the factors deserving our attention, as we balance the costs and benefits of security.

\section{A. Reduced Monitoring Efforts}

Overinvestment can be contained either through modifying debtors' incentives or through monitoring their behaviors. As discussed previously, while secured debts may sometimes suppress debtors' adverse incentives, they also tend to weaken lenders' motivation to monitor. In the presence of nonadjusting creditors, the reduced monitoring efforts of secured parties enhance the debtor's chance to invest in an excessively risky manner. When the available investment opportunities compel the borrower to undertake the efficient project only if secured borrowing scales down its total cost of capital, issuance of secured debts improves the overall social

Creditor 2's interest charge drops to zero, and the more efficient Project 1 will be undertaken.

127. E.g. Adler, Secured Credit, supra note 50, at 406 (explaining that if early creditors have priority, subsequent creditors will protect themselves by charging higher interest rates, which will increase the cost for the debtor); Kanda \& Levmore, supra note 4, at 2113 (stating that "a first-in-time priority system is a more practical means of solving the risk alteration problem"); Triantis, Free-Cash-Flow, supra note 77, at 2163 (stating that granting priority to first-in-time creditors prevents debtors from obtaining credit for subsequent risky gambles). 
welfare by saving monitoring costs and any residual cost of overinvestment due to incomplete monitoring (assuming the costs of secured borrowing themselves are not too high).

In contrast, when secured lending is unable to align private and social interests given a certain investment opportunity set, unsecured debts may bring about additional monitoring to reduce the likelihood of overinvestment, or they may simply cut off the costs associated with the issuance of secured debts. These points can be seen from the following examples.

Example 3. Firm is a risk-neutral debtor. The value of Firm's own asset, which can be used as collateral, is $\$ 1,000$. This value does not change with the outcome of prospective investments. Suppose that the interest rate for a risk-free loan is zero. At $t_{0}$, Firm issues a debt of $\$ 1,000$, secured or unsecured, to a risk-neutral adjusting Creditor 2 in order to finance the investment in one of the following two projects. Project 1 has an upside of $\$ 3,000$, and its probability of success is $50 \%$. The upside of Project 2 is $\$ 12,000$, and its probability of success is $10 \%$. Both projects yield nothing if they fail. At $\mathrm{t}_{1}$, after the debt is issued, Firm makes a choice between these two projects. The outcomes of these projects become clear at $t_{2}$. In addition, Firm's other creditor, Creditor 1, has an outstanding unsecured credit of $\$ 500$ and is completely ignorant of the riskiness of its credit, so it charges zero interest regardless of Firm's investment and financing strategies. Firm's obligations to both creditors mature at $t_{2}$, and it will go bankrupt if the total amount of debt obligations exceeds its asset value. ${ }^{128}$ Let us also assume that Creditor 2's monitoring effort can lower Firm's chance to invest in the riskier Project 2 by $50 \%$ at a cost of $\$ 50$. Finally, the cost involved in issuing a secured debt is $\$ 20$.

When Creditor 2's lending is secured, its loan is subject to essentially no risk, so the creditor is not likely to be enthusiastic about monitoring the debtor. ${ }^{129}$ In this case, Firm will choose Project 1 since its net gain from this option is $50 \%(3,000-1,000-500+1,000)-(1,000-500)-20=\$ 730$, greater than the net gain from Project 2 , which equals $10 \%(12,000-1,000$ $500+1,000)-(1,000-500)-20=\$ 630$. Accordingly, the gain of the society, net of the cost, is $50 \% * 3,000-1,000-20=\$ 480$.

128. As in the previous examples, the interest of the loan is assumed not to be included in Creditor 2's bankruptcy claim.

129. In fact, it is Firm who does not want monitoring as the cost of monitoring will be borne eventually by Firm, yet no benefit (i.e., any reduction in the amount of loan interest) can be reaped from monitoring since the monitor's loan is riskless whether it monitors or not. See supra Part III.B. for a discussion of the monitoring efficiency argument in favor of secured debt. 
On the other hand, if its loan is unsecured, Creditor 2 will receive a pro rata distribution when Firm is bankrupt. So its prospect of recovering the debt depends on Firm's investment strategy, and Creditor 2 will take into account the cost of lending by adjusting the interest charge for the loan. If Creditor 2 does not monitor and Firm is hence free to engage in Project 2, the amount of interest, $r_{n}$, can be calculated by solving the equation $10 \%\left(1,000+r_{n}\right)+90 \% * 1,000 * 1,000 /(500+1,000)=1,000$, i.e. $\$ 3,000{ }^{130}$ Therefore, Firm's net gain without monitoring is $10 \%(12,000$ $1,500-3,000+1,000)-500=\$ 350$. In contrast, if monitoring occurs, the interest of the loan, $r_{y}$, will be $\$ 944$, the solution to $50 \%\left[10 \%\left(1,000+r_{y}\right)+\right.$ $90 \% * 1,000 * 1,000 /(500+1,000)]+50 \%\left[50 \%\left(1,000+\mathrm{r}_{\mathrm{y}}\right)+\right.$ $50 \% * 1,000 * 1,000 /(500+1,000)]=1,000+50 .{ }^{131}$ Firm's net gain now rises to $50 \% * 10 \%(12,000-1,500-944+1,000)+50 \% * 50 \%(3,000-1,500-$ $944+1,000)-500=\$ 416.8$. In other words, when a secured debt with full priority is not allowed, Firm will require monitoring and invest in either project with an equal chance. As a result, the net social payoff is $50 \% * 50 \% * 3,000+50 \% * 10 \% * 12,000-1,000-50=\$ 300$. Obviously, our social welfare increases when secured lending is allowed. So this example presents a case where the balance between overinvestment control and monitoring inspiration tilts in favor of the employment of security interests.

Example 4. Assume the upside of riskier Project 2 turns to $\$ 13,200$, while all other conditions remain the same as Example 3. In this case, Firm will choose Project 2 if secured lending is allowed, since it will be better off by $10 \%(13,200-1,500+1,000)-500-20=\$ 750$, rather than $\$ 730$, the net gain from investing in Project 1. Accordingly, the net social payoff becomes $10 \% * 13,200-1,000-20=\$ 300$.

If Creditor 2 cannot obtain priority in bankruptcy via secured lending, however, Firm will require monitoring by Creditor 2 so that there is only a $50 \%$ chance that it invests in Project 2. This can be seen from the following calculation. Since Creditor 2's risk of lending stays unchanged, monitoring or not, it will continue to charge $r_{n}=\$ 3,000$ when it does not monitor, and $r_{y}=\$ 944$ when it does. Under this interest schedule, Firm will invest in Project 2 without monitoring; hence, its net gain is $10 \%(13,200$

130. $r_{n}$ cannot be the solution to $50 \%\left(1,000+r_{n}\right)+50 \% * 1,000 * 1,000 /(500+1,000)=$ 1,000 , i.e., $\$ 333$, since a rational Firm would not pick Project 1 when the amount of interest is $\$ 333$. Firm's net gains from Project 1 and Project 2 , respectively, can be calculated as $50 \%(3,000-1,500-333+1,000)-500=\$ 583.5$ and $10 \%(12,000-1,500-333+1,000)-500=$ $\$ 616.7$.

131. It can be verified that when the interest charged is $\$ 944$, Firm is still better off by investing in Project 2 since 50\%(3,000-1,500-944+1,000) - 500 = $\$ 278<10 \%(12,000$ $1,500-944+1,000)-500=\$ 555.6$. 
$1,500-3,000+1,000)-500=\$ 470$. On the other hand, Firm will lose a $50 \%$ chance to pick the riskier project if Creditor 2 monitors, but its net gain will rise to $50 \% * 10 \%(13,200-1,500-944+1,000)+50 \% * 50 \%(3,000$ $1,500-944+1,000)-500=\$ 476.8$.

Therefore, we can force Firm to accept monitoring by removing the priority status held by secured lenders, and the social welfare will be enhanced consequently, for the net social gain becomes $50 \% * 50 \% * 3,000+$ $50 \% * 10 \% * 13,200-1,000-50=\$ 360, \$ 60$ higher than if security interests with full priority are permitted. In this example, we are presented with a situation where the tradeoff between monitoring and overinvestment control leads to a case for abandoning the full priority of secured claims in bankruptcy.

Example 5. Assume the upside of the riskier Project 2 increases to $\$ 14,000$ and that all other conditions remain the same as Example 3. Now, Firm will invest in Project 2 regardless of whether the borrowing is secured or not. If a secured loan is used, Project 2 yields a net private gain of $10 \%(14,000-1,500+1,000)-500-20=\$ 830$, while Project 1 still yields $\$ 730$. On the other hand, if Creditor 2 is not secured, under the creditor's surveillance, Firm can reap a net gain of 50\%*10\%(14,000-1,500-944 $+1,000)+50 \% * 50 \%(3,000-1,500-944+1,000)-500=\$ 516.8$ whereas Firm's net gain will rise to $10 \%(14,000-1,500-3,000+1,000)-500=\$ 550$ when it is free from monitoring. ${ }^{132}$

In this case, we cannot effectively overcome the overinvestment problem regardless of whether the secured leading is allowed or not. Considering the cost of issuing secured debts, removing this choice from the borrower nevertheless improves efficiency.

The above examples have demonstrated that when the costs of issuing secured debts and monitoring debtor misbehavior are kept constant, the relative efficiency of secured vis-à-vis unsecured lending depends on the investment opportunity sets that the debtor encounters. Therefore, no easy comparison can be made unless we have some knowledge about the potential distribution of these opportunity sets. On the other hand, for any given set of investment options, the costs of monitoring and awarding security interests will determine the efficiency calculus of secured and unsecured lending.

To illustrate, suppose in Example 3 the cost of issuing a secured loan is not $\$ 20$, but $\$ 250$. Secured lending then generates a net social gain of

132. Note that the interest charged by Creditor 2 will still be $\$ 944$ when it monitors and $\$ 3,000$ when it does not, since the risk of the unsecured loan remains unchanged throughout these three examples. 
$50 \% * 3,000-1,000-250=\$ 250$, lower than what society would obtain should secured lending be prohibited. ${ }^{133}$ Second, suppose Creditor 2 is such an efficient monitor that, in Example 3, its monitoring, at a cost of \$5, can reduce Firm's chance of investing in Project 2 by $98 \%$. Accordingly, Creditor 2 will charge an interest of $r_{y}$ equal to $\$ 354$ when it advances an unsecured loan and conducts monitoring. ${ }^{134}$ Confronted with such a lowcost monitor, Firm will ask for monitoring voluntarily when secured lending is not an option ${ }^{135}$; hence, the net social gain climbs to $98 \% * 50 \% * 3,000+2 \% * 10 \% * 12,000-1,000-5=\$ 489$ from $\$ 480$ when secured lending is allowed. In short, society appears to be better off, in terms of aggregate welfare, in a world without full-priority security.

\section{B. Distorted Incentive to Take Precaution}

As explained in C.3 of Part II, it has been well understood that secured debts with full priority distort the borrower's decisions to take precaution against potential tort damages. Considering the advantage of suppressing overinvestment, however, the relative efficiency of secured versus unsecured lending again varies from case to case, depending on the investment opportunities available to the borrower. The following two examples illustrate the variability in this comparison.

Example 6. Firm is a risk-neutral debtor. The value of Firm's own asset, which can be used as collateral, is $\$ 1,000$, and this value does not change with the outcome of prospective investments. Suppose the interest rate for a risk-free loan is zero. At $t_{0}$, Firm issues a debt of $\$ 1,000$, secured or unsecured, to a risk-neutral adjusting Creditor 2 in order to finance the investment in one of the following two projects. Project 1 has an upside of $\$ 4,000$, and its probability of success is $50 \%$. The upside of Project 2 is $\$ 7,200$, and its probability of success is $25 \%$. If failed, both projects yield nothing. Firm makes a choice between these two projects at $t_{1}$, after the debt is issued. The outcomes of these projects become clear at $t_{2}$. Moreover, Firm's operation may cause a harm of $\$ 1,500$ to another party,

133. Note that Firm will still prefer granting a security interest and investing in Project 1 when secured lending is allowed, even if the cost of issuing secured debt rises to $\$ 250$ because by doing so its net gain amounts to $\$ 500$. This figure is higher than the maximum amount of net private gain, $\$ 416.8$, when it borrows an unsecured debt.

134. $98 \%\left[50 \%\left(1,000+r_{y}\right)+50 \% * 1,000 * 1,000 /(500+1,000)\right]+2 \%\left[10 \%\left(1,000+r_{y}\right)+\right.$ $90 \% * 1,000 * 1,000 /(500+1,000)]=1,000+5$

135. This strategy brings Firm a net gain of $98 \% * 50 \%(3,000-1,500-354+1,000)+$ $2 \% * 10 \%(12,000-1,500-354+1,000)-500=\$ 573.83$, whereas no monitoring and $100 \%$ investment in Project 2 still brings it $\$ 350$. But secured lending enables Firm to realize an even higher net gain of $\$ 730$. 
Creditor 1 , which occurs sometime between $\mathrm{t}_{0}$ and $\mathrm{t}_{2}$ with a $50 \%$ chance, but Firm can incur $\$ 500$ to take precaution at $\mathrm{t}_{0}$ to avoid this harm. The occurrence of the harm is independent from the success of Firm's investment, and Firm will have to pay $\$ 1,500$ in damages at $t_{2}$ if it does occur. Firm also needs to repay Creditor 2 at $\mathrm{t}_{2}$, and it will go bankrupt if the total amount of debt obligations exceeds its asset value. Assume that issuing a secured debt is costless and that creditor monitoring is impossible.

When Creditor 2's loan is secured and Firm takes precaution, only $\$ 500$ will be left to repay the loan in case of investment failure. So Creditor 2 will charge $\$ 1,500$ as the interest of the loan. ${ }^{136}$ Accordingly, Firm will undertake Project 2 and its net private gain will be $25 \%(7,200$ $1,000-1,500+500)-1,000=\$ 300$. But if Firm does not incur any cost to take precaution, it will have $\$ 1,000$ to pay back the secured loan advanced by Creditor 2 since the existence of Creditor 1 does not alter the priority status held by the secured lender. Hence, the loan becomes riskless and its interest drops to zero. Then, we will expect Firm to invest in Project 1 and obtain a net gain of $50 \%(4,000-1,000+1,000)-50 \% * 50 \% * 1,500-1,000=$ $\$ 625 .^{137}$ Obviously, Firm prefers investing in Project 1 and not taking precaution when a secured debt is used. Therefore, the net social gain from this option is $4,000 * 50 \%-1,000-50 \% * 1,500=\$ 250$.

Conversely, if the loan is not secured, taking precaution will generate the same payoff for Firm as when it takes precaution and the loan is secured, because precaution eliminates the probability of harm and Creditor 2 will always be Firm's sole creditor. But Creditor 1's claim for damages will arise with $50 \%$ chance if Firm does not take precaution, and then Creditor 2 will be subject to pro rata distribution with Creditor 1 if its loan is unsecured and Firm goes bankrupt. Aware of this risk, the unsecured Creditor 2 would charge Firm an interest equal to $\$ 900$ should it not take precaution. ${ }^{138}$ As a result, secured lending not allowed, Firm will choose not to take precaution and invest in Project 2, earning a net gain of $25 \%(7,200-1,000-900+1,000)-25 \% * 50 \% * 1,500-1,000=\$ 387.5 .^{139}$ Our society, therefore, gains $7,200 * 25 \%-1,000-50 \% * 1,500=\$ 50$.

In this example, banning secured loans does not encourage precaution,

136. Solve $25 \%(\mathrm{r}+1,000)+75 \% * 500=1,000$, where $\mathrm{r}$ is the amount of interest. Note that Firm will play opportunistically to invest in Project 2 if the interest is set at $\$ 500$, the solution to $50 \%(\mathrm{r}+1,000)+50 \% * 500=1,000$.

137. In this case, Firm will not pick Project 2 since $25 \%(7,200-1,000+1,000)$ $25 \% * 50 \% * 1,500-1,000=\$ 612.5<\$ 625$.

138. Solve $25 \%(\mathrm{r}+1,000)+75 \%(50 \% * 1,000+50 \% * 1,000 * 2 / 5)=1,000$, where $\mathrm{r}$ is the amount of interest. Note it is not incentive compatible for Firm to invest in Project 1 if the interest is set at $\$ 300$, by solving $50 \%(\mathrm{r}+1,000)+50 \%(50 \% * 1,000+50 \% * 1,000 * 2 / 5)=$ 1,000 .

139. Remember that Firm's net gain, if it takes precaution, is only $\$ 300$. 
but instead leads to higher cost of capital, thus intensifying overinvestment incentives. Therefore, overall social welfare is sacrificed when secured lending is not an available option. But this inefficiency arises because of the particular investment opportunity set available to the borrower. If the borrower is presented with a different opportunity set, unsecured lending may encourage precaution without provoking overinvestment, hence improving social welfare as illustrated in the next example.

Example 7. The upside of Project 2 drops to $\$ 6,700$, all other conditions being the same as Example 6 .

Now, if the loan is secured and precaution is taken, Firm can credibly commit itself to Project 1 at the interest level of $\$ 500$, which causes Creditor 2 to break even. ${ }^{140}$ Nevertheless, not taking precaution is still a better option insofar as the loan is secured. ${ }^{141}$ In other words, Firm, when using a secured debt, will make the same choice as in the previous example - investing in Project 1 and not taking precaution - and thus the resulting net social gain will also be the same as in the previous example, i.e., $\$ 250$.

On the other hand, Firm will invest in Project 1 again but choose to take precaution if it is barred from issuing secured debts. Incurring the $\$ 500$ cost for precaution, Firm can expect a net benefit of $\$ 500$ from its investment in Project $1 .^{142}$ But if it does not spend on precaution, Firm will have to pay the unsecured Creditor 2 an interest of $\$ 300,{ }^{143}$ which drives its net gain down to $50 \%(4,000-1,000-300+1,000)-(50 \% * 50 \% * 1,500)-$ $1,000=\$ 475$. Therefore, spending on precaution becomes a wise choice for Firm, which renders the net social gain up to $50 \% * 4,000-1,000-500$ $=\$ 500$. Apparently, with a decrease in the upside of the riskier project, unsecured lending may encourage efficient precaution against tortious harm without triggering additional costs of overinvestment.

There is yet another issue regarding the tradeoff between precaution inefficiency and overinvestment efficiency of secured debts. Given a set of investment opportunities, the borrower's incentive to take precaution diminishes as the cost of doing so increases. While commentators often seem to ignore the cost effect on decisions to take precaution, ${ }^{144}$ it may actually force up the interest charge in a way similar to the diluting effect

140. $25 \%(6,700-1,000-500+500)-1,000=\$ 425<50 \%(4,000-1,000-500+500)-$ $1,000=\$ 500$.

141. Firm's net gains, when taking precaution and not doing so are, respectively, $50 \%(4,000-1,000-500+500)-1,000=\$ 500$ and $50 \%(4,000-1,000+1,000)$ $50 \% * 50 \% * 1,500-1,000=\$ 625$.

142. See id.

143. Solve $50 \%(\mathrm{r}+1,000)+50 \%(50 \% * 1,000+50 \% * 1,000 * 2 / 5)=1,000$.

144. E.g., Bebchuk \& Fried, Uneasy Case 2, supra note 5, at 1319; Bebchuk \& Fried, Uneasy Case 1, supra note 5, at 898-900. 
of tort claims. As long as the cost of precaution is to be paid out of the borrower's pocket, it also reduces the borrower's assets available for bankruptcy distribution to its adjusting creditors, the same as what is expected upon the appearance of tort creditors when no precaution is taken. Foreseeing less recovery when the borrower goes bankrupt, adjusting creditors will account for the increased risk by raising the interest rate, regardless of the driving force of the risk increase. From the borrower's standpoint, therefore, the rising cost of precaution can render precaution less appealing than staying careless and allowing tort claims to build up, ceteris paribus. ${ }^{145}$ This point is shown by Example 8 .

Example 8. The cost of taking precaution rises to $\$ 700$, all other conditions being the same as Example 7.

Under the secured lending arrangement, taking precaution pushes the loan interest up to $\$ 2,100^{146}$ and Firm's net gain becomes $-\$ 25 .^{147}$ But if no cost is incurred to take precaution, Firm's net gain will be $\$ 625$ again. ${ }^{148}$ Apparently, Firm would prefer the latter option, creating a positive social gain of $\$ 250$, the same as in the previous example.

When unsecured, Creditor 2 will charge an interest of $\$ 300$ if Firm does not take precaution ${ }^{149}$ and $\$ 2,100$ if it does. ${ }^{150}$ Accordingly, Firm's net private gain will be, respectively, $\$ 475^{151}$ and $-\$ 25{ }^{152}$ Clearly, when the cost of taking precaution rises to $\$ 700$, Firm will not be ready to incur this cost even though it is not allowed to issue secured debts. The social gain is still $50 \% * 4,000-1,000-50 \% * 1,500=\$ 250$. Hence, in this example, our society should be indifferent whether secured loans are allowed.

Therefore, just like our discussion about monitoring, when we consider the distortive effects of precaution decisions, no simple conclusion can be drawn as to the desirability of secured lending without any knowledge about the distribution of the borrower's investment opportunities, or the cost involved in reducing the probability of accident to

145. Note that under the limited liability regime, the borrower can externalize the costs of torts even when the loan is not secured. Thus, investing in precaution forces the borrower to bear all the costs of avoiding the harm, but only enjoy part of the benefits. Consequently, it may not pay for the borrower to invest in precaution despite the investment being socially optimal.

146. Solve $25 \%(r+1,000)+75 \% * 300=1,000$, where $r$ is the amount of interest. Note it is not incentive compatible for Firm to invest in Project 1 if the interest is set at $\$ 700$, by solving $50 \%(\mathrm{r}+1,000)+50 \% * 300=1,000$.

147. $25 \%(6,700-1,000-2,100+300)-1,000=-\$ 25$.

148. $50 \%(4,000+1,000-1,000)-50 \% * 50 \% * 1,500-1,000=\$ 625$.

149. See supra note 143 .

150. See supra note 146.

151. See supra note 143 and accompanying text.

152. See supra note 147. 
an optimal level. ${ }^{153}$

\section{OTHER ISSUES}

In the preceding parts of this Article, the analysis centers on the impact of secured lending on debtors' overinvesting incentives. Below I will briefly discuss another two topics appearing in the literature about the efficiency of secured lending and explore whether they are affected likewise by the primary paradox of secured lending.

\section{A. A Note on Underinvestment}

Underinvestment refers to the situation where, due to pre-existing debt obligations, the borrower is willing to forego some efficient investment opportunities with positive NPV. Since it was identified in the late $1970 \mathrm{~s},{ }^{154}$ law scholars have widely recognized its presence and appreciated the role of secured lending in its solution. ${ }^{155}$ In particular, Professors Bebchuk and Fried believe that underinvestment is a main efficiency cost if the full priority system is transformed into a partial priority one. ${ }^{156}$

With an analysis similar to the one in Part III. B., we may conclude that secured debts, coupled with full priority, are able to assuage underinvestment when the borrower's investment opportunity set includes at least one socially efficient project. First, if both projects are socially efficient, yet the borrower is not interested in either for lack of net private gain, a secured debt raises the net earnings from these projects as the interest charges, $\mathrm{R}_{\mathrm{C} 1}$ and $\mathrm{R}_{\mathrm{C} 2}$, shrink, hence improving the probability that one of these projects will be undertaken. That is to say, secured debts

153. Needless to say, as discussed in the previous section, the cost involved in the use of secured debts is another factor.

154. For the seminal work on underinvestment, see Stewart C. Myers, Determinants of Corporate Borrowing, 5 J. FIN. ECON. 147 (1977) (presenting an explanation for why firms limit borrowing even with a tax advantage).

155. Stulz and Johnson first indicate that secured lending facilitates the solution to the underinvestment problem. See Rene M. Stulz \& Herb Johnson, An Analysis of Secured Debt, 14 J. Fin. ECON. 501, 515-17 (1985) (noting that financing a project with secured debt often involves lower monitoring and contracting costs). For analysis of this point in the legal literature, see, for example, Triantis, Secured Debt, supra note 4, at 238, 248-49 (illustrating the subset of cases where investment could be financed by the issuance of secured debt).

156. See Bebchuk \& Fried, Uneasy Case 1, supra note 5, at 919-20 (illustrating when shareholders may choose to undertake an efficient activity). The author's illustration and description of the situation revealed their interest in the underinvestment problem although the term was not explicitly mentioned. They also believe that this should be a rare situation but did not elaborate on the basis for their belief. 
make it easier to satisfy either the combination of inequalities (7) and (8) or of (2) and (9). Second, if only Project 1 is efficient, and unsecured borrowing will not lead to a net gain to the borrower from investing in either project, secured lending may incentivize it to undertake the efficient project by reducing $\mathrm{R}_{\mathrm{Cl}}$, the interest of the loan. In other words, secured lending elevates the likelihood that inequalities (7) and (8) are jointly satisfied. Of course, in the latter situation, the smaller amount of interest accompanied by a secured debt may propel the investment in the inefficient Project 2 as well when it engenders a concurrent fulfillment of both (2) and (9) as the borrower is faced with certain sets of investment opportunities. Law scholars have long been aware of the dual efficiency effects of granting security interests to adjusting creditors. ${ }^{157}$

A necessary condition for secured lending to exert its positive influence on underinvestment is, again, W-N-R $\mathrm{R}_{\mathrm{N}} \geq \mathrm{p}_{2}\left[\mathrm{x}_{2}-\mathrm{C}-\mathrm{R}_{\mathrm{C} 2}(0)-\mathrm{N}-\right.$ $\left.\mathrm{R}_{\mathrm{N}}+\mathrm{W}\right]$. When W-N- $\mathrm{R}_{\mathrm{N}}<\mathrm{p}_{2}\left[\mathrm{x}_{2}-\mathrm{C}-\mathrm{R}_{\mathrm{C} 2}(0)-\mathrm{N}-\mathrm{R}_{\mathrm{N}}+\mathrm{W}\right]$ and $\mathrm{p}_{1}\left[\mathrm{x}_{1}-\mathrm{C}-\mathrm{R}_{\mathrm{Cl}}(0)-\mathrm{N}-\right.$ $\left.\mathrm{R}_{\mathrm{N}}+\mathrm{W}\right] \leq \mathrm{p}_{2}\left[\mathrm{x}_{2}-\mathrm{C}-\mathrm{R}_{\mathrm{Cl}}(0)-\mathrm{N}-\mathrm{R}_{\mathrm{N}}+\mathrm{W}\right]$, the debtor will invest in Project 2 even if secured borrowing is unavailable. Likewise, when $\mathrm{W}-\mathrm{N}-\mathrm{R}_{\mathrm{N}}<\mathrm{p}_{2}\left[\mathrm{x}_{2}-\mathrm{C}-\right.$ $\left.\mathrm{R}_{\mathrm{C} 2}(0)-\mathrm{N}-\mathrm{R}_{\mathrm{N}}+\mathrm{W}\right]$ but $\mathrm{p}_{1}\left[\mathrm{x}_{1}-\mathrm{C}-\mathrm{R}_{\mathrm{Cl}}(0)-\mathrm{N}-\mathrm{R}_{\mathrm{N}}+\mathrm{W}\right]>\mathrm{p}_{2}\left[\mathrm{x}_{2}-\mathrm{C}-\mathrm{R}_{\mathrm{Cl}}(0)-\mathrm{N}-\mathrm{R}_{\mathrm{N}}+\mathrm{W}\right]$, the debtor will invest in Project 1 even when it can borrow only on unsecured basis. This is because, given $\mathrm{p}_{1}\left[\mathrm{x}_{1}-\mathrm{C}-\mathrm{R}_{\mathrm{Cl}}(0)-\mathrm{N}-\mathrm{R}_{\mathrm{N}}+\mathrm{W}\right]>\mathrm{p}_{2}\left[\mathrm{x}_{2}-\right.$ $\left.\mathrm{C}-\mathrm{R}_{\mathrm{Cl}}(0)-\mathrm{N}-\mathrm{R}_{\mathrm{N}}+\mathrm{W}\right], \mathrm{p}_{1}\left[\mathrm{x}_{1}-\mathrm{C}-\mathrm{R}_{\mathrm{Cl}}(0)-\mathrm{N}-\mathrm{R}_{\mathrm{N}}+\mathrm{W}\right]$ must be greater than $\mathrm{p}_{2}\left[\mathrm{x}_{2}-\mathrm{C}-\right.$ $\left.\mathrm{R}_{\mathrm{C} 2}(0)-\mathrm{N}-\mathrm{R}_{\mathrm{N}}+\mathrm{W}\right]{ }^{158}$ so $\mathrm{W}-\mathrm{N}-\mathrm{R}_{\mathrm{N}}<\mathrm{p}_{1}\left[\mathrm{x}_{1}-\mathrm{C}-\mathrm{R}_{\mathrm{Cl}}(0)-\mathrm{N}-\mathrm{R}_{\mathrm{N}}+\mathrm{W}\right]$. Put differently, as long as W-N- $\mathrm{R}_{\mathrm{N}}<\mathrm{p}_{2}\left[\mathrm{x}_{2}-\mathrm{C}-\mathrm{R}_{\mathrm{C} 2}(0)-\mathrm{N}-\mathrm{R}_{\mathrm{N}}+\mathrm{W}\right]$, the debtor will always invest in some project, rather than abstaining from all opportunities. ${ }^{159}$ Therefore, it seems that the merit of secured lending in overcoming underinvestment occurs when $\mathrm{p}_{2} \mathrm{x}_{2}$, the expected value of the riskier investment project, is relatively low.

For the purpose of this Article, it is most important to note that the merit of secured lending in overcoming underinvestment relies again on the presence of nonadjusting creditors. In other words, this efficient aspect of secured lending finds itself subject to the primary paradox too. This point is evident from the fact that the borrower's incentive of investment is determined by its entire cost of credit, $\mathrm{R}_{\mathrm{Ci}}+\mathrm{R}_{\mathrm{N}}$. Secured debts reduce this cost only because we have assumed that $R_{N}$ is fixed. If, instead, the unsecured creditor raises its interest rate after a secured debt is issued to

157. E.g., Triantis, Free-Cash-Flow, supra note 77, at 2162-64 (giving an example situation of the tradeoff between first-in-time and later-in-time priority rules).

158. Since $\mathrm{R}_{\mathrm{C} 1}(0)<\mathrm{R}_{\mathrm{C} 2}(0), \mathrm{p}_{2}\left[\mathrm{x}_{2}-\mathrm{C}-\mathrm{R}_{\mathrm{C} 1}(0)-\mathrm{N}-\mathrm{R}_{\mathrm{N}}+\mathrm{W}\right]>\mathrm{p}_{2}\left[\mathrm{x}_{2}-\mathrm{C}-\mathrm{R}_{\mathrm{C} 2}(0)-\mathrm{N}-\mathrm{R}_{\mathrm{N}}+\mathrm{W}\right]$.

159. Admittedly, when only Project 1 is socially efficient, the debtor may nonetheless opt for Project 2 and forego the efficient project when W-N-R $\mathrm{R}_{\mathrm{N}}<\mathrm{p}_{2}\left[\mathrm{x}_{2}-\mathrm{C}-\mathrm{R}_{\mathrm{C} 2}(0)-\mathrm{N}-\mathrm{R}_{\mathrm{N}}+\mathrm{W}\right]$. But this is considered as a problem of overinvestment instead of underinvestment, and secured lending facilitates its solution, as discussed in Part IV.A. 
other creditors, the overall cost of capital stays unaltered. Then, secured lending cannot be a cure for underinvestment.

\section{B. A Note on Screening Efficiency}

Professor Buckley asserts that the screening costs of unsecured creditors will be reduced if security interests are granted to some creditors because "unsecured creditors can usually assume that $B_{u}=0$ and need not estimate how many other claims will be made on bankruptcy." 160 So, under secured lending, only a smaller number of secured creditors have to engage in screening with respect to their bankruptcy rights. This argument, as Professor Triantis has precisely pointed out, is overly simplified since unsecured creditors often do receive partial repayment of their claims in bankruptcy. ${ }^{161}$ It is plausible that, after the issuance of secured debts, unsecured creditors tend to screen the borrower more intensively. They will have to bear increased risk when other lenders enjoy a priority in bankruptcy, so every extra dollar spent on screening will preserve their stakes by a greater margin. ${ }^{162}$

While both Professors Buckley and Triantis seem to believe that when secured debts are issued, the unsecured creditors' will screen less extensively because "they may be able to rely on the screening activity of the collateral given to prior lenders," 163 I remain suspicious of the validity of this postulation. Two factors contribute to the fact that unsecured creditors may duplicate the screening efforts of secured creditors. First, the outcomes of screening can be concealed as private information so that there is no guarantee that secured creditors' screening will be a public good to all creditors. In other words, unsecured creditors will need to collect information by themselves despite the screening efforts of prior secured creditors. Second, unsecured creditors are probably unwilling to dispense with the evaluation of collaterals when such information is kept private by secured lenders. Secured creditors may hold a sufficient equity cushion such that unsecured creditors might still be able to rely on the collaterals for partial repayment of their claims in bankruptcy. In addition, if, as

160. Buckley, supra note 4, at 1424. Professor Buckley uses $B_{u}$ to denote the value of the unsecured creditors' bankruptcy claim at default. See id. at 1399 (defining $B_{u}$ ).

161. Triantis, Secured Debt, supra note 4, at 251 (commenting that creditors, if they did assume that they would receive nothing in bankruptcy, would undervalue a firm's debt and any resulting loss would offset what was saved from screening costs).

162. Professor Triantis expressed a similar concern, though he may not agree that the adjusting unsecured creditors' overall screening costs would rise accordingly. See id. (pointing out that the unsecured creditors may be focused on unencumbered assets or the firm's general financial health while relying on previous screening activity).

163. Id. 
Professor Triantis has suggested, unsecured creditors can truly count on the screening of collaterals by prior lenders, hence lowering the total screening costs, then we should see secured debts issued as early as possible in the debtor's business life, which, unfortunately, finds no empirical support. ${ }^{164}$ Thus, augmented intensity plus comparable extensity implies increased screening costs for the unsecured creditors who adjust their screening activities when other lenders are secured.

From the social perspective, what matters is always the entire cost of capital rather than the partial cost associated with secured credits. So, just like any other type of capital cost, the overall screening cost will not decline, even if secured creditors incur lower screening costs, unless some unsecured creditors do not expand their expenditure on screening as a result of secured lending. If such unsecured creditors do exist, they are very likely the nonadjusting creditors affected by the distributional effects of secured debts. In this sense, even the screening efficiency does not seem to be relieved from the primary paradox of secured lending.

\section{CONCLUSION}

Is there a less uneasy case for the priority of secured claims in bankruptcy? The answer may be a qualified yes. On the one hand, since Professors Bebchuk and Fried did not identify the advantage of secured lending in moderating overinvestment with the presence of nonadjusting creditors, ${ }^{165}$ the case for the priority of secured claims may not be as troubling as they have perceived. In comparison with underinvestment, overinvestment is probably more intractable through renegotiation among the parties. ${ }^{166}$ So dispiriting the latter can be a bigger merit than relieving the former. On the other hand, however, this paper has also shown that even this efficiency benefit relies heavily on the distributional effects of

164. See Schwartz, Security Interests, supra note 3, at 22 (arguing that the validity of the staggering-debt explanation is questionable, as data is sparse and those statistics that are available fail to support it).

165. They believe the only desirable investment activity that will be sacrificed after the priority of secured claims is restricted will be, essentially, the one susceptible to underinvestment. See Bebchuk \& Fried, Uneasy Case 1, supra note 5, at 920 (discussing only the situation in which a firm may need additional investment). So the benefit of controlling overinvestment explored in this paper is distinct from those efficiency gains they have considered.

166. Renegotiation has long been considered a solution to underinvestment. See Bebchuk \& Fried, Uneasy Case 1, supra note 5, at 920-21 (noting that creditors may find it in their interest to modify their contractual rights and reduce the size of their claims, so that they are able to receive full payment on reduced claims rather than no payment on their full claims); Myers, supra note 154, at 158 (presenting when and how a debt contract might be renegotiated). 
secured lending, and that secured debts not only tame the overinvesting incentive but can also inspire it under a different set of conditions.

As elaborated in this Article, the virtue of secured debts in discouraging overinvestment under some circumstances should be weighed, first of all, against its vice in stimulating overinvestment under others. Further trade-offs exist between this virtue and the dampened monitoring efforts, distorted precaution decisions, as well as costly perfection requirements and complicated bankruptcy dynamics. In view of all these hurdles before an efficient employment of secured financing, any extra relief for the uneasy case of the priority of secured credits may appear insignificant.

The two paradoxes examined in this Article exhibit the complexity of assessing the welfare effects of secured lending. The distribution of borrowers' investment opportunities, lenders' monitoring abilities, the costs necessary for optimal level of precaution, the costs of issuing secured debts, and their ramifications in the bankruptcy procedure, among other things, will all exert influence on the overall efficiency of secured lending. Usually, when lawmakers do not have sufficient information about the costs and benefits of certain activities, it is advisable to make the person who decides to take action bear all the burdens and enjoy all the rewards of his or her decision. But in the current case, this strategy is not going to work. The quantity of agency costs involved in debt financing varies as the parties that shoulder these costs vary. If the borrower is forced to internalize the entire agency costs, the total amount of such costs may become greater than what it otherwise would be when nonadjusting creditors share part of these costs. In other words, internalization, though it eliminates distribution, may downsize the social welfare pie at the same time.

Although we are, by and large, still agnostic about the significance of secured lending in curing adverse incentives relative to its impact on distributing agency costs, a more recent study by Professor Listokin has shed important light on the severity of distributional effects in practice. ${ }^{167}$ Based on a carefully designed empirical strategy, he has managed to demonstrate that secured debts are less frequently used by industries with large, uninsurable tort liabilities, probably due to the considerable costs in bankruptcy. ${ }^{168}$ This finding, however, is not necessarily good news for advocates of security interests with bankruptcy priority. If Professor

167. Listokin, supra note 2 (providing a study on the redistributional theory in bankruptcy).

168. Id. at 1077 (concluding that secured debt is the least attractive debt when the probability of liquidity defaults is relatively high, such as in the case of massive tort bankruptcies). 
Listokin's observation is correct, then the primary paradox this paper has reviewed would predict that the efficiency created by secured lending, should it exist, is trivial as well. In that case, the controversy about the priority status of secured claims in bankruptcy itself becomes normatively unimportant. Another implication is that the proprietary aspect of security interests might be more relevant to their allocative efficiency. Thus, the welfare effects of security interests, when stripped of priority, probably warrant a meticulous probe in future. ${ }^{169}$

169. For instance, one question in need of further exploration is whether a secured creditor's threat to foreclose becomes less credible. See supra note 53 (discussing factors affecting the credibility of threatening foreclosure as a deterrence to debtor misbehaviors). Relatedly, reconsideration may also be warranted about the very idea of separating the property and priority sides of security interests. It is worth noting that property interests on borrowers' assets, in general, enjoy a status senior to debt obligations in bankruptcy proceedings. See Baird, supra note 28, at 120 (pointing to $\S 365(\mathrm{~h})$ of the Bankruptcy Code). 